\title{
Potential water quality changes due to corn expansion in the Upper Mississippi River Basin
}

\author{
Silvia Secchi, ${ }^{1,6}$ Philip W. Gassman, ${ }^{2}$ Manoj Jha,${ }^{3}$ Lyubov Kurkalova, ${ }^{4}$ and Catherine L. Kling ${ }^{2,5}$ \\ ${ }^{1}$ Department of Agribusiness Economics, Southern Illinois University, Carbondale, Illinois 62901 USA \\ ${ }^{2}$ Center for Agricultural and Rural Development, Iowa State University, Ames, Iowa 50011 USA \\ ${ }^{3}$ Civil Engineering Department, North Carolina A\&T State University, Greensboro, North Carolina 27411 USA \\ ${ }^{4}$ Department of Economics and Finance, North Carolina A\&T University, Greensboro, North Carolina 27411 USA \\ ${ }^{5}$ Department of Economics, Iowa State University, Ames, Iowa 50011 USA
}

Abstract. While biofuels may yield renewable fuel benefits, there could be downsides in terms of water quality and other environmental stressors, particularly if corn is relied upon exclusively as the feedstock. The consequences of increased corn production will depend importantly on where (and how) the additional corn is grown, which, in turn, depends on the characteristics of land and its associated profitability. Previous work has relied on rules of thumb for allocating land to increased acreage based on historical land use or other heuristics. Here, we advance our understanding of these phenomena by describing a modeling system that links an economics-driven land use model with a watershed-based water quality model for the Upper Mississippi River Basin (UMRB). This modeling system is used to assess the water quality changes due to increased corn acreage, which is associated with higher relative corn prices. We focus on six scenarios based on six realistic pairs of corn and soybean prices which correspond to a scale of decreasing soybean to corn price ratio. These price-driven land use changes provide estimates of the water quality effects that current biofuel policies may have in the UMRB. Our analysis can help evaluate the costs and environmental consequences associated with implementation strategies for the biofuel mandates of the new energy bill. The amounts of total N and P delivered to the outlet of the UMRB (located at Grafton, Illinois, USA) rise as corn production becomes more intensive in the region. Our results indicate that a $14.4 \%$ in corn acreage in the watershed due to corn intensification in the most economically profitable locations would result in a 5.4\% increase in total nitrogen loads and in a $4.1 \%$ increase in total phosphorus loads at Grafton. Our most aggressive scenario, driven by high but not out of reach crop prices, results in about a $57 \%$ increase in corn acreage with a corresponding $18.5 \%$ increase in $\mathrm{N}$ and $12 \%$ increase in P. These are somewhat conservative increases in nutrients, compared to those of previous studies, likely due to our focus on cultivated cropland which is already heavily fertilized.

Key words: biofuels; corn; Upper Mississippi River Basin; water quality; water quality modeling.

\section{INTRODUCTION}

Unprecedented increases in biofuel production are occurring: the United States now produces nine billion gallons of ethanol compared to less than two billion in 2002 (Renewable Fuels Association 2010; 1 gallon $=3.79$ L). As of January 2010, 200 biorefineries were operating in the United States, with 11 more under construction (Renewable Fuels Association 2010). Although the ethanol industry has been hit hard by the current economic crisis, and the rapid fall in oil prices and demand for gasoline, its long-term prospects remain

Manuscript received 10 April 2009; revised 20 January 2010; accepted 5 February 2010; final version received 12 March 2010. Corresponding Editor: A. R. Townsend. For reprints of this Invited Feature, see footnote 1, p. 1037.

${ }^{6}$ E-mail: ssecchi@siu.edu good given the direction of U.S. energy policy. For example, the latest energy bill, the Energy Independence and Security Act of 2007 (EISA 2007), mandates 36 billion gallons of ethanol by 2022 with 15 billion coming from corn. The remaining 21 billion gallons are expected to come from second-generation technologies that currently are not commercially viable, such as cellulosic ethanol.

The increased demand for corn has brought equally unprecedented price increases and returns to farmers, particularly in the fertile Corn Belt. This has the potential to increase corn production, as witnessed in 2007. While the renewable nature of ethanol and other biofuels is environmentally appealing to many, others have raised concerns about the potential environmental degradation associated with biofuel production, especially via the current technology, corn-starch-based ethanol. The issue is very complex, since biofuel feed- 
stocks are being produced throughout the globe, and these land-based energy sources compete at least in part with food, feed, and fiber production. The concerns have become very broad in scope, because they now include the direct and indirect land use effects associated with biofuels production, and the related net effects on greenhouse gas emissions (Fargione et al. 2008, Kline et al. 2008, Searchinger et al. 2008, Melillo et al. 2009), and biodiversity, air quality, soil erosion, and water quality on a global scale and a wide variety of landscapes, from forests and savannahs to cultivated cropland (Naylor et al. 2007, Koh and Ghazoul 2008, Robertson et al. 2008). Concerns related to water quality are particularly troublesome in the Upper Mississippi River Basin (UMRB), as nitrogen from corn production (see Plate 1) is often cited as a contributor to Gulf of Mexico hypoxia and local water quality concerns throughout the Midwest (EPA Science Advisory Board 2008). A large body of literature has investigated the link between agricultural activities and hypoxia in the Gulf. Turner and Rabalais (2003) relate 200 years of anthropogenic changes in the whole Mississippi to water quality, and conclude that fertilizer applications play a dominant role in the increase in nitrates in the river. While recent studies also call attention to the role of phosphorus in the enlargement of the hypoxic zone, nitrogen fluxes are still seen as critical drivers (Lohrenz et al. 1997, 1999, Sylvan et al. 2006, Alexander et al. 2008). The 1999 Integrated Assessment on Hypoxia in the Gulf of Mexico also attributed to fertilizer use a dominant role: the report estimated that $90 \%$ of the nitrogen and phosphorus discharged into the Gulf were due to nonpoint sources. (Goolsby et al. 1999). As part of the Integrated Assessment, a suite of management strategies were proposed for the Mississippi River Basin to significantly reduce nitrogen loads (Mitsch et al. 2001). Besides being linked to the hypoxic zone in the Gulf of Mexico, these nutrients also contribute to poor local water quality problems within many areas of the UMRB (Turner and Rabalais 2003, Royer et al. 2006, Oquist et al. 2007, Secchi et al. 2007).

The production of large amounts of ethanol has the potential to increase the hypoxic zone. Indeed, Simpson et al. (2008) conclude that the recent expansion of corn production will dramatically increase nutrient loads to both surface and ground waters. Likewise, Donner and Kucharik (2008) conclude that meeting the EISA 2007 goals of expanded ethanol will make meeting the goals of reducing Gulf hypoxia "practically impossible without large shifts in food production and agricultural management."

In this study, we use an integrated economic and water quality modeling framework for the Upper Mississippi River Basin (UMRB) to conduct scenario analysis to shed light on potential water quality changes associated with ethanol production, with a focus on the key driver of corn prices. Previous studies investigating the historical link between agricultural activities and water quality in the Mississippi have used regression based models (Goolsby et al. 1999, Goolsby and Battaglin 2001) or hybrid statistical and process based approaches (Alexander et al. 2008). These models were not directly linked to agricultural management activities and were not constructed for scenario analysis.

Our research is motivated by an overarching question: How many additional nutrients ( $\mathrm{N}$ and $\mathrm{P}$ ) are likely to end up in the rivers and streams of the UMRB as a result of land use and management changes due to the increases in the relative profitability of corn?

Like the work by Simpson et al. (2008), we investigate the water quality changes associated with expanded corn-based ethanol, but take an alternative approach: we use a calibrated watershed-based water quality model to predict the water quality changes associated with spatially explicit predicted placement of expanded corn acreage. Our approach also differs from the methodology recently used by Donner and Kucharik (2008), who assessed the effect of expanded ethanol production by combining county-level maps with remotely sensed land use data and integrating the Agro-IBIS biosphere model with the THMB transport model. Their study relied on heuristics to allocate quantities of corn production at the county level, a useful methodology for identifying aggregate effects from quantity mandates. Our approach differs in that we use economic models to simulate price-based responses of farmers' behavior and the associated land use changes, which ties land use decisions directly to their economic basis. We also consider phosphorous as well as nitrogen export, an important addition because, as previously noted, phosphorous is now understood to contribute to hypoxic conditions in the Gulf. Numerous water quality models exist that have been developed for analyzing various environmental problems for specific scales as documented in extensive literature reviews (e.g., Singh 1995, Shepherd et al. 1999, Borah and Bera 2003, Borah et al. 2006, Srivastava et al. 2007, Breuer et al. 2008). One of the most widely used of these models is the Soil and Water Assessment Tool (SWAT), a watershed-scale water quality model (Arnold et al. 1998, Arnold and Fohrer 2005, Gassman et al. 2007), which we used in this study both to simulate the UMRB hydrologic balance and to estimate the changes in nutrient (phosphorous and nitrogen) and sediment loadings in response to alternative crop choices and rotation changes. SWAT has been successfully applied worldwide to replicate observed hydrologic and/or pollutant losses across a wide range of watershed scales and environmental conditions, and for numerous conservation practice, land use, climate change and other scenario studies, as documented by Gassman et al. (2007) for over 200 peerreviewed SWAT-related studies. The model has also been applied in several studies for the entire UMRB (Arnold et al. 2000, Jha et al. 2004b, 2006a, b, Wu and Tanaka 2005, Gassman et al. 2006, Kling et al. 2006, Takle et al. 2006; S. Rabotyagov et al. 2010) or for 
TABLE 1. Some key policy and economic drivers of the ethanol expansion.

\begin{tabular}{|c|c|c|}
\hline Year & Policy & Effect \\
\hline 1975 & Lead phase-out begins & Ethanol becomes attractive as octane booster. \\
\hline 1978 & Energy Tax Act & $\begin{array}{l}\text { A } \$ 0.40 \text { subsidy per gallon of ethanol blended into gasoline } \\
\text { introduced. }\end{array}$ \\
\hline $1980-1984$ & $\begin{array}{l}\text { Energy Security Act, Crude Windfall Tax Act, } \\
\text { Surface Transportation Act, Tax Reform Act }\end{array}$ & $\begin{array}{l}\text { Insured loans for small ethanol producers, tariffs on foreign } \\
\text { produced ethanol, ethanol subsidy increased to } \$ 0.50 \text { and } \\
\text { then } \$ 0.60 \text {. }\end{array}$ \\
\hline 1992 & Clean Air Act amendments & $\begin{array}{l}\text { Mandated oxygenates in many locations, MTBEs major } \\
\text { oxygenate in use. }\end{array}$ \\
\hline $1985-2003$ & Various acts & $\begin{array}{l}\text { Subsidy reduced gradually to } \$ 0.52 / \text { gallon. Various states } \\
\text { banned MTBEs. }\end{array}$ \\
\hline 2005 & Energy Policy Act & $\begin{array}{l}\text { Phased out MTBEs as oxygenate thereby increasing demand } \\
\text { for ethanol. }\end{array}$ \\
\hline 2007 & Energy Bill & Biofuels mandate for 36 billion gallons by 2022 . \\
\hline 2008 & Farm Bill & Decrease corn ethanol tax credit to $\$ 0.45 /$ gallon. \\
\hline
\end{tabular}

Notes: MTBE stands for methyl tert-butyl ether; 1 gallon $=3.79 \mathrm{~L}$.

selected UMRB subwatersheds including applications described by Arnold and Allen (1996), Jha et al. (2003, 2004a, 2007), Santelman et al. (2004), Muleta and Nicklow (2005), Bekele and Nicklow (2005), Schomberg et al. (2005), Reungsang et al. (2007), and Secchi et al. (2007).

Our modeling framework allows us to estimate the impacts of market forces through price effects. Since our modeling system is constructed to include the spatial placement of crops based on economic considerations and/or environmental suitability, it can also be used to inform a wide range of future policies related to agricultural land use and conservation. The model could be applied to assess the land use and water quality changes of price-based policies, such as conservation payments or subsidies, or policies based on environmental characteristics, for example erodibility or proximity to streams, which may be devised to limit some of the environmental impacts of corn expansion.

As noted earlier, crop prices have changed dramatically in recent years. The reasons behind these large changes in prices remain the subject of intense debate. Most analysts point to a variety of causes, ranging from rising energy prices, a low dollar, rising food demand from historically low income countries, trade policies in some parts of the world, to, most relevant for our discussion, ethanol policy which has raised the returns to corn production relative to other crops (Food and Agricultural Policy Research Institute 2009, USDA 2009). A brief review of some of the ethanol policy drivers is contained in Table 1. Several legislative acts have encouraged the production of ethanol over the last three decades. Most notable are the ethanol subsidies which have ranged from $\$ 0.40$ to $\$ 0.60$ per gallon over the period (all prices are presented in US\$). These subsidies have made ethanol competitive with gasoline as a fuel source, particularly as the price of gasoline has increased over the past decade. The last Energy and Farm bills left the support structure for corn ethanol largely untouched. In fact, the possibility being currently discussed of raising the blend wall would expand market opportunities for the industry even further. (The blend wall refers to the regulatory cap imposed on the percentage of ethanol that can be mixed into gas, and the associated limits that the wall imposes on ethanol consumption, given that the flex fuel vehicles are still a very small percentage of the U.S. fleet. The current wall is $10 \%$.) Even though recent long-term projections have been lower than the prices in the last two years, which were influenced by short term shortages, according to the U.S. Department of Agriculture (USDA), prices are expected to remain well over historical averages in the next 10 years, because of the long term effects we mentioned, including biofuels policies (USDA 2009). These policies raise the demand for corn for use as a feedstock for ethanol. Therefore, corn prices are expected to stay high, which in turn, could be associated with high levels of corn acreage in the UMRB (USDA 2009). Since corn is typically associated with higher nutrient use and loss (Balkcom et al. 2003, Randall et al. 2003), this has led many to suggest that a side effect of the policies that have expanded ethanol production is worsening water quality. By comparing the water quality predictions from our modeling system at current crop prices with water quality predictions under higher relative corn prices we provide evidence on the magnitude of these changes. Our analysis is in line with large scale crop production models such as the one housed at the Center for Agricultural and Rural Development at Iowa State University, which predict that the UMRB will continue to be a major corn producing and exporting area in the future, as the watershed's land has a comparative advantage in corn production (Tokgoz et al. 2007).

\section{Landuse and Ethanol Policy Drivers in the UMRB}

Fig. 1 contains a map of the UMRB, which is the watershed that runs from the source of the Mississippi river in Minnesota to Cairo, Illinois, USA. The economic results are reported for the whole area, but the hydrological model is calibrated at the gage at Grafton, thereby excluding the "orphan" part of the 


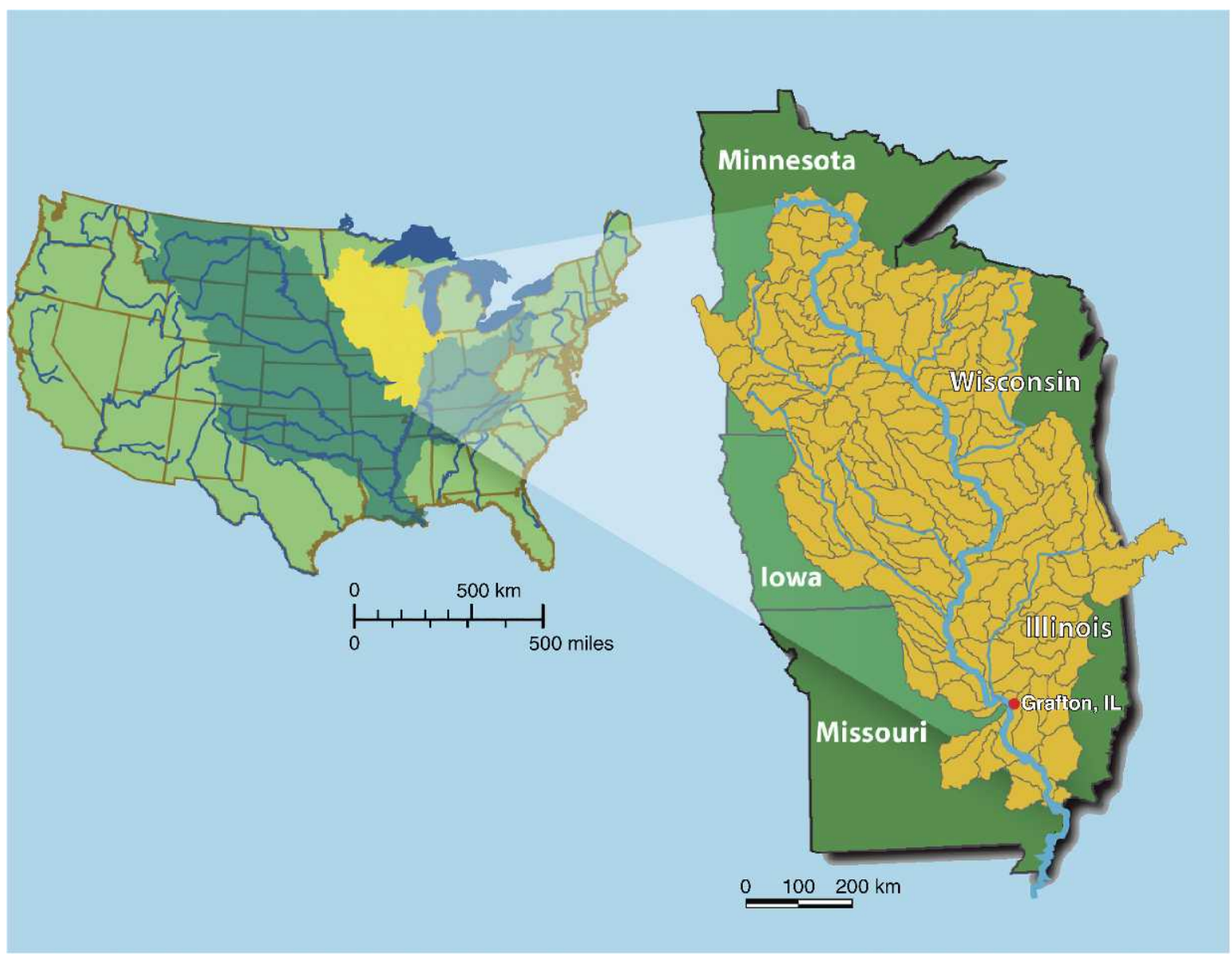

FIG. 1. The Upper Mississippi River Basin (UMRB).

watershed between the confluence of the Missouri and the Ohio River (Hydrologic Unit Code or HUC 7014 according to the U.S. Geological Survey classification, see Seaber et al. [1987]). The reason is that, in order to include this portion of the watershed in the hydrological analysis, water quality data on the whole Missouri drainage area would be needed. The total drainage area covers portions of seven states, but the main states included in the watershed are five. Cropland and pasture account for about two-thirds of the total land area (National Audubon Society 2000).

The extensive cropland coverage of the region is depicted in Fig. 2 based on the 1997 National Resources Inventory (NRI; Nusser and Goebel 1997). In the most intensive agricultural portions of the Basin, well over $75 \%$ of the land is devoted to agricultural uses. Table 2 contains a summary of the acreage of key crops in the region. These acreages are the outcome of thousands of decisions by individual farmers and landowners concerning what crop to plant each year and in what rotation. Their decisions depend on the profitability of a cropping system. Farmers choose the most profitable cropping system and the associated management choices (such as fertilizer rates and tillage regimes) on the basis of the soils, climate, slope, and other physical factors of the land they farm, which determine potential yields, as well as the prevailing crop prices, and the cost of inputs (fertilizer, fuel, labor, etc.).

The land use coverage in 1997 represents the choices made under the crop and input prices typical of that period. Corn prices ran about $\$ 78.74-\$ 118.11 /$ ton $(\$ 2-$ $\$ 3 /$ bushel $[1$ ton $=907.18 \mathrm{~kg} ; 1$ bushel $=35.24 \mathrm{~L}]$ ) throughout the $1990 \mathrm{~s}$ and soybean prices ranged between about \$183.72-US\$275.58/ton (\$5 and \$7.5/ bushel). Fig. 3 shows the major agricultural land use categories in the five states that encompass the watershed (time series data for the UMRB itself are not available by year). Acreages have remained relatively stable since the end of the 1990s, with the exception of a corn acreage increase in 2007, which was not maintained in 2008, as the figure shows (U.S. Department of Agriculture National Agricultural Statistical Service 2009). Thus, the 1997 baseline still broadly reflects the watershed's land use. The data in Fig. 3 also illustrate the almost one-to-one correspondence between corn and soybean acreage in the Midwest in the last 15 years. As we discussed previously, beginning in 2005, there have been large and rapid changes of both absolute and 

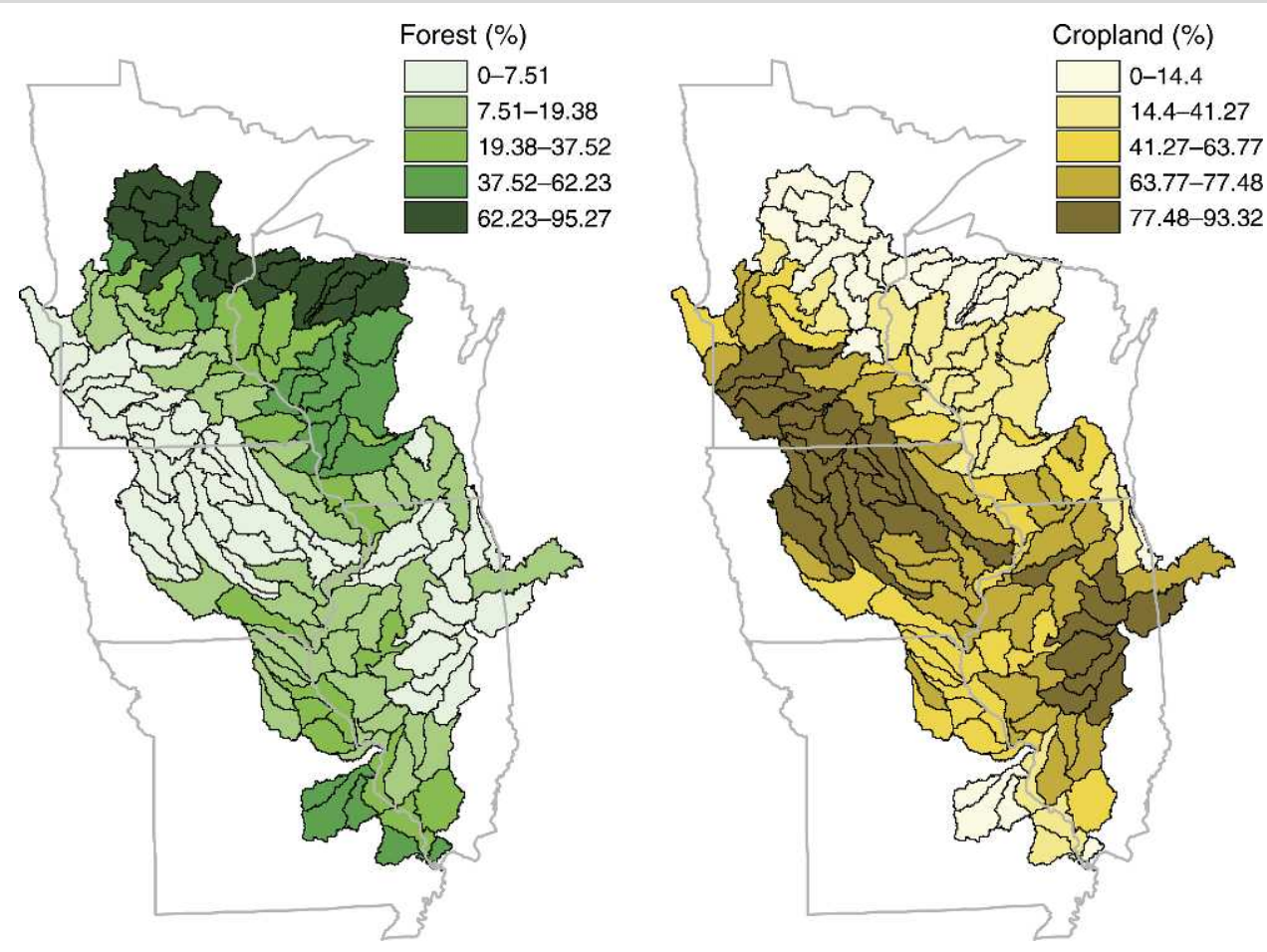

FIG. 2. Land use in the UMRB watershed according to the 1997 National Resources Inventory.

relative prices for both corn and soybeans. As commodity and input prices are the most important drivers of farmers' choices, sizable changes in land use patterns cannot be ruled out if price changes continue and/or are sustained for long periods. We return to the issue of prices as drivers of land use and forecasts in the section where we describe the scenarios we simulated. In general, higher relative corn prices alter crop planting decisions. In particular, the most likely expansion of corn production will occur by shifting from cornsoybean, which is the historically dominant cropping rotation in the Corn Belt, to more use of continuous corn or corn-corn-soybean rotations. The change in cropping patterns in the UMRB has the potential to reduce water quality in the region. Understanding the magnitude of these changes will be essential if policies to mitigate or counteract them are to be implemented.

\section{The Integrated Modeling System}

Our integrated modeling framework incorporates the spatial heterogeneity in the region and integrates micro behavior and natural system responses over small units, rather than relying on typical agent behavior or average physical responses in the landscape. Using the data and models detailed in the next section, we generate a baseline scenario. This baseline is then compared to several counterfactual scenarios, which illustrate the effects of expanded corn acreage in land that was being used for row crop production in the baseline. The expansion of corn acreage occurs mostly because of changes in crop rotations. Because of the uncertainty associated with forecasting crop prices, and their importance as a driver in farmers' decisions, we use a variety of commodity prices that reflect a wide range of

TABLE 2. Commodity prices and corresponding land use changes in the Upper Mississippi River Basin.

\begin{tabular}{|c|c|c|c|c|c|c|c|c|c|c|}
\hline Scenario & $\begin{array}{c}\text { Corn } \\
\text { (US\$/Mg) }\end{array}$ & $\begin{array}{c}\text { Corn } \\
\text { (US\$/bushel) }\end{array}$ & $\begin{array}{c}\text { Soybean } \\
\text { (US\$/Mg) }\end{array}$ & $\begin{array}{c}\text { Soybean } \\
\text { (US\$/bushel) }\end{array}$ & $\begin{array}{c}\text { Soybean/corn } \\
\text { price ratio } \dagger\end{array}$ & $\begin{array}{c}\text { Alfalfa } \\
\text { (US\$/Mg) }\end{array}$ & $\begin{array}{c}\text { Alfalfa } \\
\text { (US\$/ton) }\end{array}$ & $\begin{array}{l}\text { Corn } \\
\text { area } \\
\left(\mathrm{km}^{2}\right)\end{array}$ & $\begin{array}{c}\text { Soybean } \\
\text { area } \\
\left(\mathrm{km}^{2}\right)\end{array}$ & $\begin{array}{c}\text { Alfalfa } \\
\text { area } \\
\left(\mathrm{km}^{2}\right)\end{array}$ \\
\hline Baseline & & & & & & & & 119783 & 84618 & 22592 \\
\hline 1 & 153.54 & 3.9 & 385.81 & 10.5 & 2.7 & 48.99 & 54 & 120316 & 94999 & 22673 \\
\hline 2 & 196.84 & 5 & 459.30 & 12.5 & 2.5 & 70.76 & 78 & 128438 & 87223 & 22442 \\
\hline 3 & 204.72 & 5.2 & 458.56 & 12.48 & 2.4 & 70.76 & 78 & 137089 & 78671 & 22376 \\
\hline 4 & 216.53 & 5.5 & 464.81 & 12.65 & 2.3 & 76.20 & 84 & 152296 & 63577 & 22300 \\
\hline 5 & 228.34 & 5.8 & 468.85 & 12.76 & 2.2 & 79.83 & 88 & 173014 & 42045 & 22844 \\
\hline 6 & 236.21 & 6 & 462.97 & 12.6 & 2.1 & 79.83 & 88 & 188118 & 27489 & 22478 \\
\hline
\end{tabular}

Note: One ton $=907.18 \mathrm{~kg}$.

$\uparrow$ The ratio is calculated from the prices in bushels. Since bushels are a measure of volume and not weight, and 56 bushels of corn and 60 of soybeans correspond to $1 \mathrm{~kg}$, there is not a one-to-one correspondence with the ratios in $\mathrm{Mg}$. 
forecasts, including the futures market and the latest Food and Agricultural Policy Research Institute (FAPRI) long-term projections. The sets of prices differ substantially both in terms of absolute and relative prices, reflecting uncertainties on several fronts, from oil prices to interest rates, but they all tend to be higher than historical prices, for the reasons previously discussed. Using several prices, ranked in a decreasing soybean to corn price ratio, allows us to translate the possible effects that world-market changes would have on the cropland of the UMRB.

Current ethanol policy subsidizes corn-based ethanol production, thereby increasing commodity prices. Our scenarios are designed to assess the likely changes in water quality in the study region due to crop price increases. It is important to note that we could have simulated quantity mandates directly. However, historically, U.S. biofuel policy has tended to operate through subsidies and blending mandates that are reflected in market prices, and the current administration is poised to implement similar policies, so this type of scenario analysis reflects realistic possible outcomes.

As noted, our modeling system uses the 1997 NRI's data delineations as the underlying unit of analysis. There are over 110000 NRI sample "points" in the UMRB, each representing a combination of weather, soil characteristics, crop choices, rotations, and other agro-ecological conditions, thus allowing the model to represent the rich economic and environmental diversity of this spatially diverse managed ecosystem. The economic model is linked to SWAT based again on the NRI. (It is important to note that several other studies have integrated economic decision models with environmental process models to evaluate policies within the UMRB; notably Wu et al. [2004], Wu and Tanaka [2005], and Booth and Campbell [2007]. For a discussion of similarities and differences in the modeling approaches see EPA Science Advisory Board [2008].) We first describe the SWAT model in detail here, including the calibration methodology, and then discuss the economic modeling component.

\section{SWAT description, input data, and calibration methodology}

The SWAT model is a conceptual, long-term continuous watershed-scale simulation model that is typically operated on a daily time step (sub-daily time step options are available). Key components of the model include hydrology, plant growth, erosion, nutrient transport and transformation, pesticide transport, and management practices; a wide array of nonlinear biological and environmental processes are captured across the hydrologic, plant growth, pollutant transport, and other major model components. The model is a very flexible tool that can simulate an extensive set of cropping systems and management and conservation practices. Watershed simulations in SWAT are configured by first dividing a watershed into endogenously

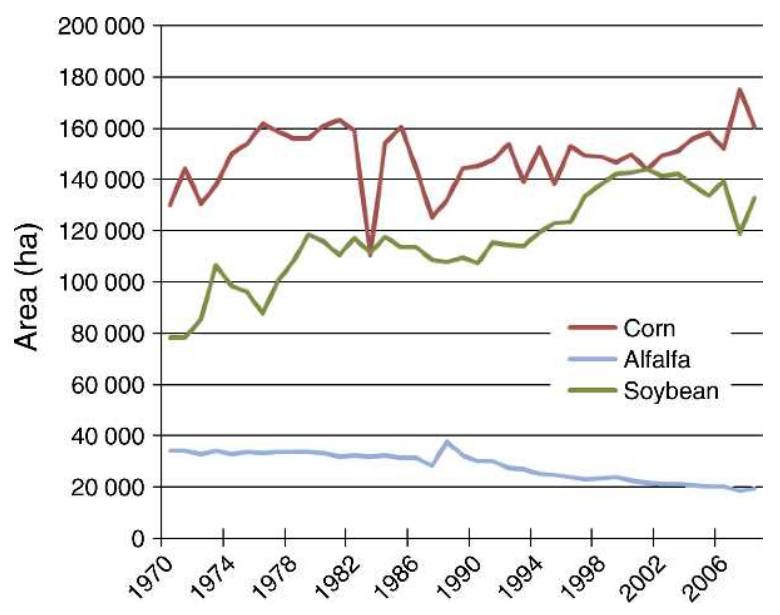

FIG. 3. Historical cropland levels in the five states of the UMRB (Illinois, Iowa, Missouri, Minnesota, and Wisconsin).

determined multiple subwatersheds on the basis of elevation, and then further subdividing the area within each subwatershed into Hydrologic Response Units (HRUs) which are composed of land with homogeneous land use, management, and soil characteristics.

Daily or sub-daily precipitation and/or irrigation (if simulated) inputs are initially accounted for at the HRU level; snowfall is also accounted for in the model if applicable and snow volumes are estimated for each HRU. Following accounting of canopy interception of precipitation inputs, the model determines the partitioning of precipitation between surface runoff and infiltration to the soil profile. Several options are available in SWAT for estimating surface runoff from each HRU; most users select a daily time step in combination with the Natural Resources Conservation Service Curve Number (CN) method (USDA-NRCS 2004). However, the Green and Ampt method (Green and Ampt 1911) in combination with sub-daily precipitation can also be used. Infiltrated subsurface water is represented by three storage volumes at the HRU level: soil profile (0-2 m), shallow aquifer (typically 2-20 m), and deep aquifer (more than $20 \mathrm{~m}$ ). Lateral subsurface flow and/or tile flow can be simulated from the soil profile as well as return flow to stream channels from the deeper aquifers. Potential evapotranspiration from the soil profile can be estimated with one of three methods: Priestly-Taylor (Priestly and Taylor 1972), Penman-Monteith (Monteith 1965), and Hargreaves (Hargreaves et al. 1985).

Nutrient cycling in SWAT is simulated via transformation and movement of nitrogen $(\mathrm{N})$ and phosphorus (P) within multiple inorganic and organic pools within each HRU. Accounting of both $\mathrm{N}$ and $\mathrm{P}$ losses occurs in SWAT via crop nutrient uptake and by movement in surface runoff in both the solution phase and on eroded sediment. Losses of $\mathrm{N}$ are also simulated in percolation to and below the soil profile, in lateral subsurface flow, tile drainage flow, and return flow, and by volatilization to the atmosphere. Movement of 
nitrate $\left(\mathrm{NO}_{3}-\mathrm{N}\right)$ in surface runoff, lateral subsurface flow, tile drainage flow, return flow, and infiltration to and through the soil profile is computed as the product of the average soil layer $\mathrm{NO}_{3}-\mathrm{N}$ concentration and the volume of water in each flow pathway. The amount of soluble $\mathrm{P}$ that is determined to be transported in surface runoff in SWAT is calculated on the basis of the solution $P$ concentration in the top $10 \mathrm{~mm}$ of soil, the surface runoff volume, and a partitioning factor. Transport of organic $\mathrm{N}$, organic $\mathrm{P}$, and inorganic (mineral) $\mathrm{P}$ on eroded sediment is determined using a loading function that was originally derived by McElroy et al. (1976) and then further modified by Williams and Hann (1978) in order to simulate movement for individual runoff events. The mass of organic $\mathrm{N}$, organic $\mathrm{P}$, or inorganic $\mathrm{P}$ determined to be lost on eroded sediment with the loading function is determined as a function of the nutrient concentration in the top $10 \mathrm{~mm}$ of soil, the surface runoff volume, and an enrichment factor, similar to the calculations of soluble $\mathrm{P}$ losses in surface runoff.

The model generates streamflow, sediment yields, nutrient loads, and other pollutant loadings for each HRU, which are then summed for a subwatershed. The subwatershed-level streamflows and loads are then routed through channels, and ponds, reservoirs, and/or wetlands if applicable, to the watershed outlet. Further documentation regarding the hydrologic, nutrient cycling, routing, and other components of SWAT are provided in Neitsch et al. $(2005 a, b)$.

The SWAT simulation framework used for this study was constructed using the 131 eight-digit hydrologic unit watersheds (eight-digit watersheds) that are within the UMRB (Fig. 1) as defined by U.S. Geological Survey (USGS 2009). These eight-digit watersheds were then subdivided into 2730 total HRUs, with sizes ranging from $5161 \mathrm{~km}^{2}$ (or about $1 \%$ of the total watershed size) to $23 \mathrm{~km}^{2}$, a median of $86 \mathrm{~km}^{2}$, and an average size of $176 \mathrm{~km}^{2}$ (standard deviation 369). Key data sources for the SWAT simulations included land use and conservation practices obtained from the NRI, digital elevation model (DEM) data from the Better Assessment Science Integrating Point and Nonpoint Sources (BASINS) package (U.S. EPA 2006), and historical climate data from the Illinois State Water Survey (J. Pan, personal communication). Fertilizer use and other survey data used in the SWAT simulations are described in more detail in Economic modeling component.

The SWAT calibration process built on previous calibration efforts for the UMRB and specific subwatersheds (Jha et al. 2003, 2004a, 2006b, 2007, Reungsang et al. 2007, and Secchi et al. 2007) and focused on testing the model at the assumed UMRB outlet at Grafton, Illinois (Fig. 1), which is located just above the confluence of the Missouri and Mississippi Rivers. The calibration process was performed by adjusting key hydrologic, sediment, and nutrient related parameters within accepted ranges and comparing the simulated output with corresponding measured data collected by the USGS at Grafton. The model was first calibrated and validated for both annual and monthly streamflow during the period 1981 to 1992 , and then calibrated for annual sediment yields, nitrate (plus nitrite) loads, and organic P loads. Validation of the calibrated parameters was then performed for the period of 1993 to 2003 without further adjustment of the calibrated parameters. The pollutant comparisons were performed on the basis of loads, which required the conversion of measured pollutant concentrations into "measured loads" using the USGS Load Estimator (LOADEST) regression model (Runkel et al. 2004).

The SWAT results were statistically evaluated using the coefficient of determination $\left(r^{2}\right)$ and Nash-Sutcliffe's coefficient (NSE; Nash and Sutcliffe 1970). Moriasi et al. (2007) developed specific criteria for several different statistics, including NSE values, based on a review of previous hydrologic and water quality modeling studies and additional pertinent information. They concluded that NSE values above 0.5 indicate satisfactory results, when judging comparisons between simulated hydrologic and pollutant loss outputs vs. corresponding measured values, for a monthly time step (and that this standard should be tightened or relaxed as appropriate when considering predicted daily or annual time step output). For this study, we used the criteria suggested by Moriasi et al. (2007) to provide guidance as to the accuracy of the SWAT results and assume that their criterion was applicable for both the NSE and $r^{2}$ statistics computed for the SWAT calibration and validation results reported in the Results and Discussion section.

\section{Economic modeling component}

The economic component of the modeling system assumes that farmers choose the crop and crop rotation for their land to maximize their net returns (profits) from farming. Thus, to predict the crop rotation and crop choice for an NRI point, and the associated crop management, we construct the costs of producing each crop under each rotation/tillage regime that is appropriate to that particular soil type, climate, and other physical characteristics. Of course, the profitability of a particular crop will also depend critically on the price of the commodity. Let us define the yield of crop $k$ in a NRI point $i$ as $Y_{k i}, P$ as the price of crop $k$ and $C_{k}$ as the costs of production for crop $k$. A farmer has a set of crops to choose from: $1 \ldots k \ldots K . Y_{k i}$ is a function of the soil type, climate, and other characteristics of the NRI point, and in our models it is taken from the SWAT simulations. $P$ varies across scenarios. The model assumes that farmers will choose the crop that maximizes net returns, that is the crop that has the highest $P_{k} Y_{k i}-C_{k}$. For simplicity of exposition, this was explained on a crop basis, but the model applies in the same way to crop rotations and associated crop management. Therefore, the crop/rotation choice will depend on profitability, which is based both on crop 
TABLE 3. Fertilizer application rates used in the simulations.

\begin{tabular}{|c|c|c|c|}
\hline \multirow[b]{2}{*}{ State } & \multicolumn{2}{|c|}{ C-S } & \multirow{2}{*}{$\frac{\mathrm{C}-\mathrm{C}}{\mathrm{N} \text { added }}$} \\
\hline & $\begin{array}{l}\mathrm{N} \text { added } \\
\text { (kg N/ha) }\end{array}$ & $\begin{array}{c}\mathrm{P} \text { added } \\
(\mathrm{kg} \mathrm{P} / \mathrm{ha})\end{array}$ & \\
\hline Illinois & 176.09 & 87.20 & 181.58 \\
\hline Iowa & 140.44 & 68.82 & 202.88 \\
\hline Minnesota & 127.89 & 57.84 & 167.01 \\
\hline Missouri & 171.99 & 63.64 & 187.19 \\
\hline Wisconsin & 98.41 & 44.39 & 122.17 \\
\hline
\end{tabular}

prices and the physical and climatic characteristics of the NRI point.

The costs of production budgets are based on Iowa costs of production for 2008 (Duffy and Smith 2008). We use the rates of fertilizer application based on historical averages calculated by USDA's Economic Research Service (ERS), which vary by state for both N (ranging from 176.10 to $98.4 \mathrm{~kg} / \mathrm{ha}$ ) and $\mathrm{P}$ (ranging from 87.2 to $44.39 \mathrm{~kg} / \mathrm{ha}$ ), as detailed in Table 3 (USDA-ERS 2007a). The ERS data are based on USDA's National Agricultural Statistical Service (NASS) agricultural chemical usage data sets. These data do not differentiate across crop rotations, even though there is agronomic evidence that continuous corn needs to receive higher levels of fertilizer (Raimbault and Vyn 1991, Katsvairo and Cox 2000, Pikul et al. 2005). Unfortunately, there is little historical large scale data on the management of continuous corn rotations. The USDA Agricultural Resource Management Survey includes information on management by crop rotations, but the survey is of limited value in our analysis to determine continuous corn rates because of its small sample size, which reflects the historically low continuous corn acreage (USDAERS 2007b). However, there is evidence that, in recent years, the continuous corn acreage has expanded due to corn price increases (Stern et al. 2008). The increase in fertilizer input use associated with continuous corn production is going to be an important factor in determining water quality in the region. Therefore, we use the Corn Nitrogen Rate Calculator to determine the rates associated with continuous corn production.

The calculator was developed by several Midwest agronomists, and it averages information on yield response functions from a large number of agronomic trial sites across the Midwest (Sawyer et al. 2006) for both corn-soybean and continuous corn rotations. It includes all the UMRB states but Missouri. For Missouri, we use the Southern Illinois calculator. For Illinois, we use the Central Illinois Calculator as it is the portion of the state with the majority of cropland. For Wisconsin, we use the highly productive soil calculator, since that is the land where corn is most likely planted. Since the USDA-ERS data are based on survey data and are indicative of actual behavior, those are the corn soybean rates we use in the analysis. To determine the continuous corn rate, we found the continuous corn rate that the calculator determined would correspond to the corn-soybean rate from USDA-ERS.

Our analysis is based on the 1997 NRI database, which includes somewhat dated Conservation Reserve Program (CRP) information (before the passing of the 1996 Farm bill that changed some of the enrollment criteria). Moreover, the future of the CRP program is uncertain, as a large number of contracts will be expiring in the near future and the recent sustained high level of crop prices substantially increases the opportunity cost of retiring land from production (Secchi et al. 2009). As a sign of the changes in the program, USDA allowed a large part of the CRP acreage to be harvested in 2008 (USDA 2008). Given the uncertainty surrounding the program, and the dated information on it available in our data set, we have chosen to focus on actively farmed cropland.

\section{Scenario Construction: Prices and Future Row Crop Land Use}

To undertake policy relevant scenarios, we need to establish historical cropping patterns in the UMRB and their associated water quality indicators, as detailed in the next section on SWAT calibration and validation, and we need to determine likely patterns of land use change, which are fundamentally related to crop prices. The recent rises in prices have made forecasting long term equilibrium prices very complicated. Since we are focusing the analysis on expanded corn acreage in land being used for row crop production in the baseline, the main issue determining the choice of crop and rotation is the relative price of soybeans to corn. If both corn and soybean prices increased by the same margin, farmers would be better off than before the price increase, but

TABLE 4. Calibration and validation for soil and water assessment tool (SWAT) streamflow and pollutant predictions at Grafton, Illinois, the assumed Upper Mississippi River Basin outlet.

\begin{tabular}{llccccc}
\hline \hline & & \multicolumn{2}{c}{ Calibration (1981-1992) } & & \multicolumn{2}{c}{ Validation (1993-2003) } \\
\cline { 3 - 3 } \multicolumn{1}{c}{ Indicator } & Time step & $R^{2}$ & NSE & & $R^{2}$ & NSE \\
\hline Streamflow & annual & 0.95 & 0.93 & & 0.93 & 0.93 \\
Streamflow & monthly & 0.81 & 0.77 & & 0.85 & 0.83 \\
Sediment & annual & 0.70 & 0.69 & & 0.93 & 0.75 \\
Nitrate + nitrite & annual & 0.48 & 0.29 & & 0.75 & 0.57 \\
Organic P & annual & 0.71 & 0.48 & & 0.79 & 0.57 \\
\hline
\end{tabular}

Note: NSE is the Nash-Sutcliffe's coefficient. 
TABLE 5. SWAT results at Grafton.

\begin{tabular}{|c|c|c|c|c|c|c|c|c|c|}
\hline \multirow[b]{2}{*}{ Scenario } & \multirow[b]{2}{*}{$\begin{array}{l}\text { Mean flow } \\
\text { out }\left(\mathrm{m}^{3} / \mathrm{s}\right)\end{array}$} & \multicolumn{2}{|c|}{ Sediment } & \multicolumn{2}{|c|}{ Total N } & \multicolumn{2}{|c|}{$\mathrm{NO}_{3}+\mathrm{NO}_{2}$} & \multicolumn{2}{|c|}{ Organic P } \\
\hline & & $\begin{array}{l}\text { Mean out } \\
\left(10^{3} \mathrm{Mg}\right)\end{array}$ & $\begin{array}{c}\text { Change from } \\
\text { the baseline } \\
(\%)\end{array}$ & $\begin{array}{l}\text { Mean out } \\
\left(10^{3} \mathrm{~kg}\right)\end{array}$ & $\begin{array}{c}\text { Change from } \\
\text { the baseline } \\
(\%)\end{array}$ & $\begin{array}{l}\text { Mean out } \\
\left(10^{3} \mathrm{~kg}\right)\end{array}$ & $\begin{array}{c}\text { Change from } \\
\text { the baseline } \\
(\%)\end{array}$ & $\begin{array}{l}\text { Mean out } \\
\left(10^{3} \mathrm{~kg}\right)\end{array}$ & $\begin{array}{c}\text { Change from } \\
\text { the baseline } \\
(\%)\end{array}$ \\
\hline Baseline & 3480 & 24016 & & 462928 & & 367030 & & 13044 & \\
\hline 1 & 3485 & 26220 & 9.2 & 475675 & 2.8 & 371187 & 1.1 & 13873 & 6.4 \\
\hline 2 & 3474 & 26067 & 8.5 & 481153 & 3.9 & 377063 & 2.7 & 13721 & 5.2 \\
\hline 3 & 3462 & 25899 & 7.8 & 487803 & 5.4 & 382705 & 4.3 & 13769 & 5.6 \\
\hline 4 & 3447 & 25582 & 6.5 & 505913 & 9.3 & 399675 & 8.9 & 13715 & 5.1 \\
\hline 5 & 3427 & 24964 & 3.9 & 527328 & 13.9 & 420442 & 14.6 & 13611 & 4.3 \\
\hline 6 & 3416 & 24896 & 3.7 & 548801 & 18.5 & 439750 & 19.8 & 13786 & 5.7 \\
\hline
\end{tabular}

this would not change the relative profitability of one crop vs. the other; hence, we would not expect to see changes in land use. Given the importance of relative prices for understanding land use decisions, we conduct the scenario analysis by identifying six realistic pairs of corn and soybean prices which correspond to a range of decreasing soybean to corn price ratios (Table 2).

We bracket the price ranges on the low end (Scenario 1) by using the 2008 FAPRI long term projections for the year 2018 forecast corn prices of $\$ 153.54 / \mathrm{Mg}(\$ 3.9 /$ bushel) and soybean prices of $\$ 385.81 / \mathrm{Mg}(\$ 10.5 /$ bushel; FAPRI 2008). The latest available 2009 FAPRI forecasts are very similar (FAPRI 2009). The comparable USDA Agricultural Projections Report (USDA 2009) has even lower prices: for 2019 their forecast is corn prices of $\$ 147.63 / \mathrm{Mg}(\$ 3.75 /$ bushel) and soybean prices of $\$ 323.34 / \mathrm{Mg}$ (\$8.8/bushel). On the high end, we use prices similar to those seen in the commodity futures markets in the Fall of 2008 for the following year that reflect a soybean to corn price ratio of 2.1 , well below the historical average and the implied ratio in the FAPRI prices (2.67). Specifically, in Scenario 6 we consider a price of $\$ 236.21 / \mathrm{Mg}$ for corn $(\$ 6 / \mathrm{bushel})$ and $\$ 462.97 / \mathrm{Mg}$ for soybean (\$12.6/bushel).

In the northern part of the UMRB, corn has been grown in rotation with alfalfa to be used for hay production. To simulate this component, we identified the prices of alfalfa corresponding to the soybean-corn prices that would keep the alfalfa acreage constant, and used them in the scenarios. The reason is that markets for hay tend to be local, due to high transportation and storage costs caused by its bulkiness (Diersen 2008). Therefore, demand for hay is inelastic for production levels higher than those that can be supported by the local livestock industry. There is no reason to expect increases in the area planted with alfalfa. In fact, alfalfa acreage in the five states of the watershed has been decreasing since the 1970s (Fig. 3). Price forecasts for hay at the national level, such as the one provided by FAPRI, have large margins of error when used to determine land use choices at a fine geographical scale. Indeed, the latest FAPRI outlook states that "Hay markets are more fragmented than markets for most other agricultural commodities, so trends in national average prices may not be reflected at the local level"
(FAPRI 2008:110). For example, according to our analysis, if alfalfa prices in the Upper Mississippi River Basin were $\$ 128.55 / \mathrm{Mg}$ (\$116.62/ton) as forecast in FAPRI's long term projections for the year 2018, and the other crop prices followed FAPRI's projections, the alfalfa acreage would almost quadruple in the UMRB. This suggests that the FAPRI forecast is likely overestimating the price of alfalfa in the watershed. Our estimates more closely reflect the relative productivity and profitability at this smaller scale.

Given these price scenarios, we use the integrated modeling system just described to perform counterfactual scenario analysis. The baseline cropping pattern (crop rotations) is derived from the NRI, which reports the crop grown in 1997 and in the three preceding years. We predict the new cropping pattern based on the price scenario and then run the calibrated SWAT model to predict the $\mathrm{N}$ and $\mathrm{P}$ loadings to the water in the region. Comparison with the baseline allows us to indicate the degree to which water quality will be altered, for better or worse, due to the relative increase in corn prices and the consequent increase in corn acreage.

As stated previously, an important agricultural land use in the region is enrollment in the Conservation Reserve Program (CRP), a government funded program that pays farmers to remove land from agricultural production and to plant environmentally friendly perennial cover. Over $17000 \mathrm{~km}^{2}$ in the region were enrolled. Enrollment in the CRP has limited length contracts, typically of $10-15$ years in duration. While the 1997 NRI identifies points that are enrolled in the CRP, many of those contracts have expired. Without an updated NRI, it is impossible to identify whether those points remained in CRP or were reclaimed for agricultural production, so we must make an assumption about that land use. The assumption we use is that the land enrolled in CRP in 1997 remains in the CRP. This allows us to construct as much as possible a ceteris paribus analysis, namely, an analysis where we focus on the impact of the change of one variable and all other variables are kept constant. Here, all the changes in water quality are coming from the intensive margin, that is, land already cropped in the baseline.

The other important assumption we make to maintain the ceteris paribus comparison is to assume that there 
TABLE 5. Extended.

\begin{tabular}{ccccc}
\hline \hline \multicolumn{2}{c}{ Mineral P } & & \multicolumn{2}{c}{ Total P } \\
\cline { 1 - 1 } \cline { 5 - 5 } $\begin{array}{c}\text { Mean out } \\
\left(10^{3} \mathrm{~kg}\right)\end{array}$ & $\begin{array}{c}\text { Change from } \\
\text { the baseline } \\
(\%)\end{array}$ & & $\begin{array}{c}\text { Mean out } \\
\left(10^{3} \mathrm{~kg}\right)\end{array}$ & $\begin{array}{c}\text { Change from } \\
\text { the baseline } \\
(\%)\end{array}$ \\
\hline 12093 & & 25137 & \\
11771 & -2.7 & & 25644 & 2.0 \\
12015 & -0.6 & & 25736 & 2.4 \\
12399 & 2.5 & & 26168 & 4.1 \\
12863 & 6.4 & & 26578 & 5.7 \\
13741 & 13.6 & 27352 & 8.8 \\
14380 & 18.9 & 28166 & 12.0 \\
\hline
\end{tabular}

are no changes in tillage systems between the baseline and the scenarios. In other words, if an NRI point was in a corn soybean no till rotation in the baseline, and it switched to continuous corn in a scenario, it is still assumed that the continuous corn is grown with a no till management. There is agronomic evidence that continuous corn yields typically decline about $3-10 \%$ in no-till regimes as the corn residue can create problems for germinating and emerging plants (Vyn et al. 2000, Wilhelm and Wortmann 2004), so movements to continuous corn systems are likely to be associated with increased use of more intensive tillage practices. Such a shift to increased tillage would result in some increased erosion and thus higher losses of sediment-bound nutrients. Thus, the implication is that our results likely would underestimate some of the environmental impacts of expanded corn production, particularly the estimates of sediment and P losses. However, the majority of the environmental shifts are captured by the increases in corn production, and the corresponding much higher uses of both $\mathrm{N}$ and $\mathrm{P}$ fertilizer inputs.

\section{Results AND Discussion}

\section{SWAT calibration and validation}

The statistical results of the SWAT baseline calibration and validation simulation are shown in Table 4 . Graphical results for the monthly streamflows and annual nitrate loads can be accessed online. ${ }^{7}$ In general the statistical results were more than adequate when considering the criteria proposed by Moriasi et al. (2007). Very strong streamflow predictions resulted as evidenced by the annual statistics that all equaled or exceeded 0.93 and the monthly streamflow results that mostly exceeded 0.8 . The weakest result was for the annual nitrate (plus nitrite) load NSE value determined during the calibration period, which was only 0.29 . This result appears to be strongly influenced by weak comparisons that occurred in a few of the calibration years, especially 1990 where the simulated nitrate load exceeded the estimated measured load by more than a factor of two. However, the results for the validation period were considerably stronger and demonstrated

\footnotetext{
${ }^{7}\langle$ http://www.public.iastate.edu/ tdc/i_swat_main.html $\rangle$
}

that the model adequately replicated the annual nitrate loads in the majority of years, and similar results occurred for the predicted sediment and organic P loads.

The calibration and validation results underscore the need for continued improvement in the estimation of nutrient inputs into the UMRB system (e.g., estimated fertilizer application rates and the need to account for manure applications) and the need for more accurate estimates of nutrient and sediment loads at Grafton, Illinois, as well as possible refinements to the SWAT nutrient cycling and sediment routing algorithms. Borah et al. (2006) compared several different models for potential applications for nutrient and sediment total daily maximum load (TMDL) analyses and concluded that the SWAT $\mathrm{N}$ and $\mathrm{P}$ nutrient cycling routines are among the most comprehensive that exist in many available models. However, they also point out that there are several limiting assumptions in the structure of SWAT nutrient cycling routines and that further research is needed to improve these routines in the model. Breuer et al. (2008) further describe improvements that were incorporated in the nitrogen cycling routine in SWAT-N, which is a variant of the standard SWAT model; similar modifications may be warranted for the standard version of SWAT. Improvements to the sediment routing structure, $\mathrm{P}$ cycling routine, and other components will be included in forthcoming releases of SWAT (J. Arnold, personal communication).

\section{Scenario analysis}

Our analysis allows us to study the spatial location of both crops and nutrient loads on a watershed basis. Tables 2 and 5 contain summary results of the six scenarios and contrast them with the baseline numbers. Recall that the higher numbered scenarios correspond to lower soybean-corn price ratios (Table 2), and thus to more intensive corn production in the UMRB. Fig. 4 illustrates the average annual corn acreage in the baseline and under Scenarios 2, 4, and 6 for each of the HUC 8 that form the SWAT sub-basins. Note that we could have also mapped fertilizer inputs this way, but they would track very closely the corn acreage. Fig. 4 shows that, as corn becomes progressively more profitable, corn production becomes more intense in central Iowa and Illinois, and in Southern Minnesota. These are the areas of the watershed with the most productive cropland, and are already under heavy agricultural use. As expected, this intensification of corn production results in increases in the amounts of $\mathrm{N}$ and $\mathrm{P}$ delivered to the outlet of the UMRB (located at Grafton, Illinois), as shown in Table 5. The table includes the absolute amounts of the increases and the corresponding percentage changes from the baseline. We report the loads for nitrates and nitrites together, and for total nitrogen loads (nitrates and nitrites plus organic $\mathrm{N}$ ). We also report the loads for organic and mineral phosphorus and their sum, as total phosphorus. Henceforth, in referring to nitrogen and phosphorus losses we refer to 


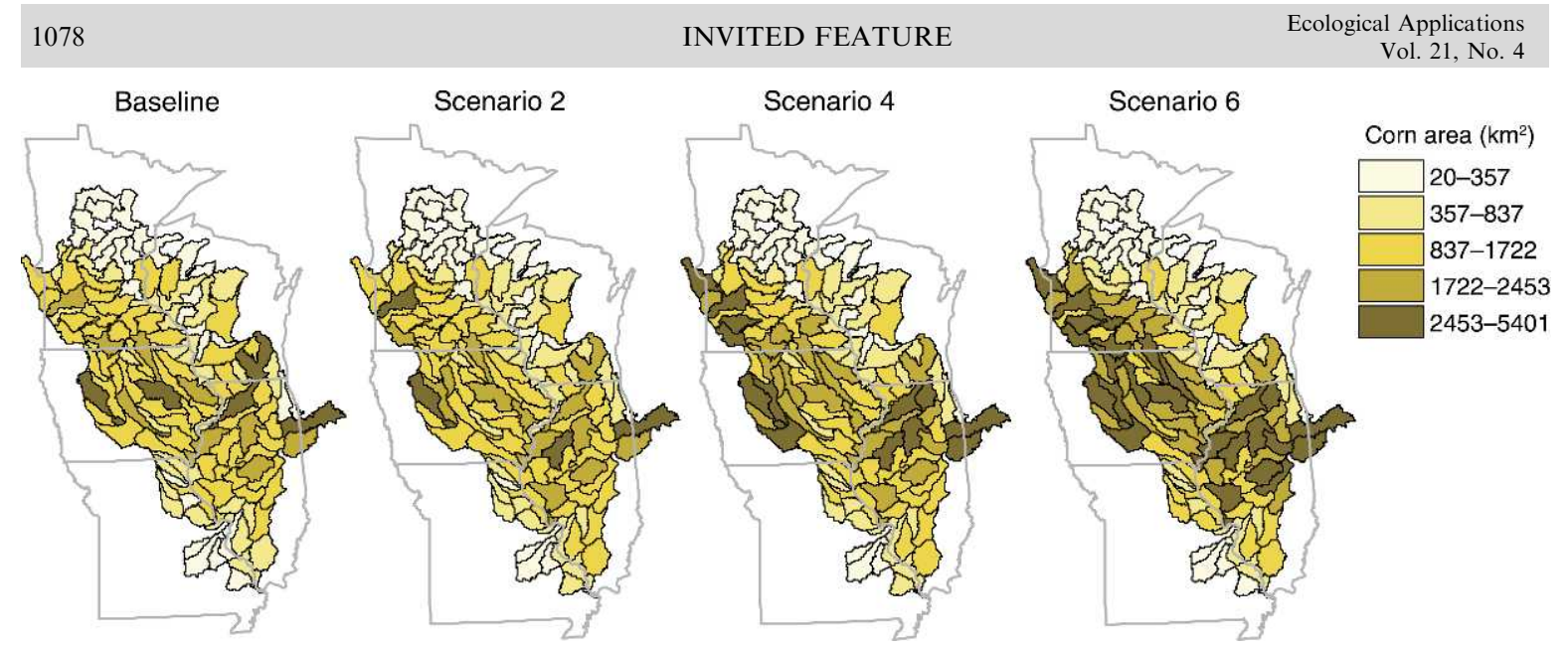

FIG. 4. Location of corn area under the baseline and Scenarios 2, 4, and 6. Values are annual averages.

total nitrogen and total phosphorus. Total percentage changes from the baseline for corn acreage, sediment, total nitrogen and total phosphorus are shown in Fig. 8. The figure shows that total nitrogen losses increase steadily as corn production intensifies. For Scenarios 3 and higher, nitrogen losses rise faster than phosphorus. Overall, the increases in nutrient losses are less than proportional to the increases in corn acreage. The main reason for this result is likely the assumption that there are no changes to the CRP land, and the increase in corn production occurs on cultivated cropland which is already heavily fertilized. Unfortunately, since the passage of the 2008 Farm Bill, USDA severely restricts access to georeferenced data, including the location of CRP land, therefore determining the fate of CRP land is going to be very difficult. Sediment loads are not dramatically affected: in fact, though they stay higher than the baseline throughout, the loads decrease as the corn area increases. This is most likely because of our tillage assumption, discussed above, that there are no changes in tillage systems between the baseline and the scenarios. If, as previously mentioned, continuous corn tends to be associated with higher tillage intensity, the effects of the land use changes we model on sediment losses could be higher.

Figs. 5, 6, and 7 provide maps for the watershed loads for sediment, nitrogen, and phosphorous under the baseline and Scenarios 2, 4, and 6 on an HUC 8 basis, and illustrate the changes in water quality at each HUC 8 outlet as corn acreage progressively increases. The location of the land use changes is an important element in determining the nutrient loads for at least two reasons. First, management practices - in particular the additional amount of nitrogen application for continuous corn - are different by state. For example, in Illinois, where we predict there could be a substantial increase in corn acreage (Fig. 4), the increase in nitrogen application associated with continuous corn production is rather small (Table 3). This is why there are few changes in nitrogen losses in the region (Fig. 6). Second, water quality changes closer to the watershed outlet are likely to have a larger measured effect than changes further upstream (Alexander et al. 2008). Therefore, some of the increases in loads that are visible in Figs. 5, 6, and 7 on a HUC 8 basis do not translate in changes downstream at the Grafton outlet.

Scenario 6 provides the highest concentration of nutrient deliveries to the Gulf and largest land use change difference from the baseline. There is a $57 \%$ increase in the corn acres compared to the baseline, and a corresponding $67 \%$ decrease in soybean acres. If the Scenario 6 prices were to prevail, Iowa and central Illinois would see tremendous increases in corn acreage. As Figs. 5, 6, and 7 show, nitrogen loads increase quite dramatically between the baseline and Scenario 6, particularly in Iowa watersheds. Phosphorus loads also increase across Iowa and central Illinois. These increases in nutrient losses from each watershed translate into substantial increases at Grafton as well. Compared with the baseline, Scenario 6 results in an increased total $\mathrm{N}$ load of about $18.5 \%$ and a corresponding increase in $\mathrm{P}$ of about $12 \%$ (see Fig. 8).

We also investigated how much it would cost to maintain existing water quality levels at the higher relative corn prices of our scenarios. Since our baseline does not have prices, we used Scenario 1 as our price baseline, as its land use and relative prices are very close to the historical baseline. We determined the rotations that offered the highest returns for farmers under Scenario 1 and all others. These were $R_{\text {MAX }}^{S x}$, where $x=$ $1,2, \ldots 6$, which are associated with the highest net returns:

$$
\operatorname{Max}_{P_{S x}}\left\{\pi^{S x}\left(R_{1}\right), \pi^{S x}\left(R_{2}\right), \ldots \pi^{S x}\left(R_{N}\right)\right\}=\pi_{\text {MAX }}^{S x}\left(R_{\text {MAX }}^{S x}\right)
$$

where $P_{S x}$ represents the prices of each scenario, and $\pi$ represents the net returns. We then calculated, under the prices of Scenario 1 to 6 , the net returns for farmers under the rotations with the highest returns, $R_{\mathrm{MAX}}^{x}$. The difference between the net returns from the most profitable rotation in Scenarios 2 to 6 and the net 


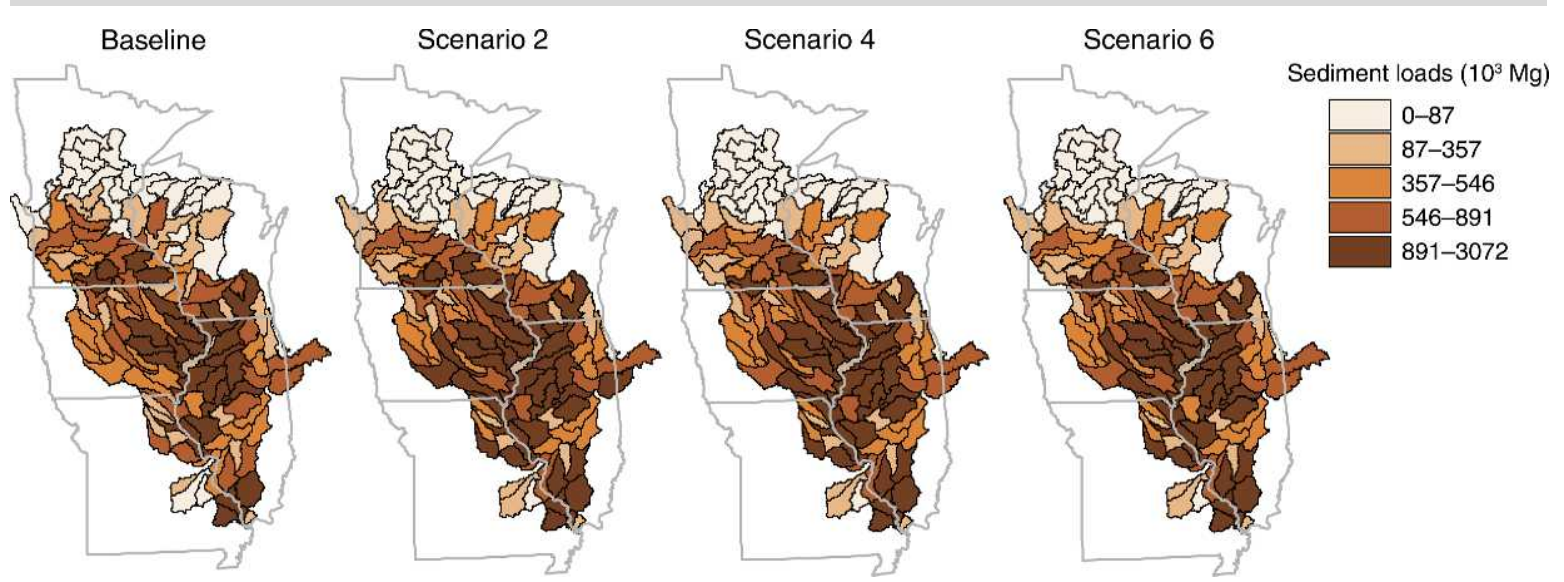

FIG. 5. Sediment loads by watershed under the baseline and Scenarios 2, 4, and 6. Values are annual averages.

returns from the most profitable rotation in Scenario 1 at the other scenario prices, represent the cost of a program in which farmers would voluntarily limit their rotation to a given baseline, and which would compensate them for their lost revenue. For example, for Scenario 4 the difference would be

$$
\pi_{\mathrm{MAX}}^{S 4}\left(R_{\mathrm{MAX}}^{S 4}\right)-\pi^{S 4}\left(R_{\mathrm{MAX}}^{S 1}\right) .
$$

Fig. 9 illustrates these results. At Scenario 4 prices, it would cost almost $\$ 1$ billion annually to maintain water quality at Grafton to Scenario 1 levels, while at Scenario 6 prices, it would cost over $\$ 3$ billion annually. Note that if the absolute prices of corn and soybeans were lower, these costs would be substantially less too, as they are for some of the other scenarios considered. The costs will generally depend both on absolute and relative crop prices, and, in practice, will also depend on input prices, which are here held constant. Nonetheless, this exercise demonstrates how the opportunity costs for voluntary programs aimed at maintaining environmental quality can be calculated from model results, and it illustrates the size of some of the tradeoffs.

\section{Policy Implications And Conclusions}

In the Mississippi River basin, fertilizer applications play a large role in the nitrogen cycle, and non point sources are the dominant source of nitrogen in riverine exports (Howarth at al. 2002). There is evidence of nonlinearity in the response of the hypoxic zone in the Gulf to changes in nitrogen loads, suggesting that restoration of water quality, even without large scale changes to the drivers of land use, may require larger efforts than previously estimated (Turner et al. 2008).

Simpson et al. (2008) conclude that the increase in corn acreage by about $15 \%$ seen from 2006 to 2007 could be expected to increase $\mathrm{N}$ loadings to the Gulf of Mexico by about $10 \%$ and $\mathrm{P}$ loadings by about $5 \%$. Our findings suggest somewhat smaller increases in $\mathrm{N}$ than these estimates predict for comparable increases in corn acreage. Our Scenario 3 yields about a $15 \%$ increase in corn acreage, yet our model predicts about half the increase in $\mathrm{N}$ loading that they do $(5.4 \%)$. On the other hand, our phosphorous estimate is quite close (ours is just over 4\%). Given the differences in data and methods employed, these estimates are surprisingly similar.
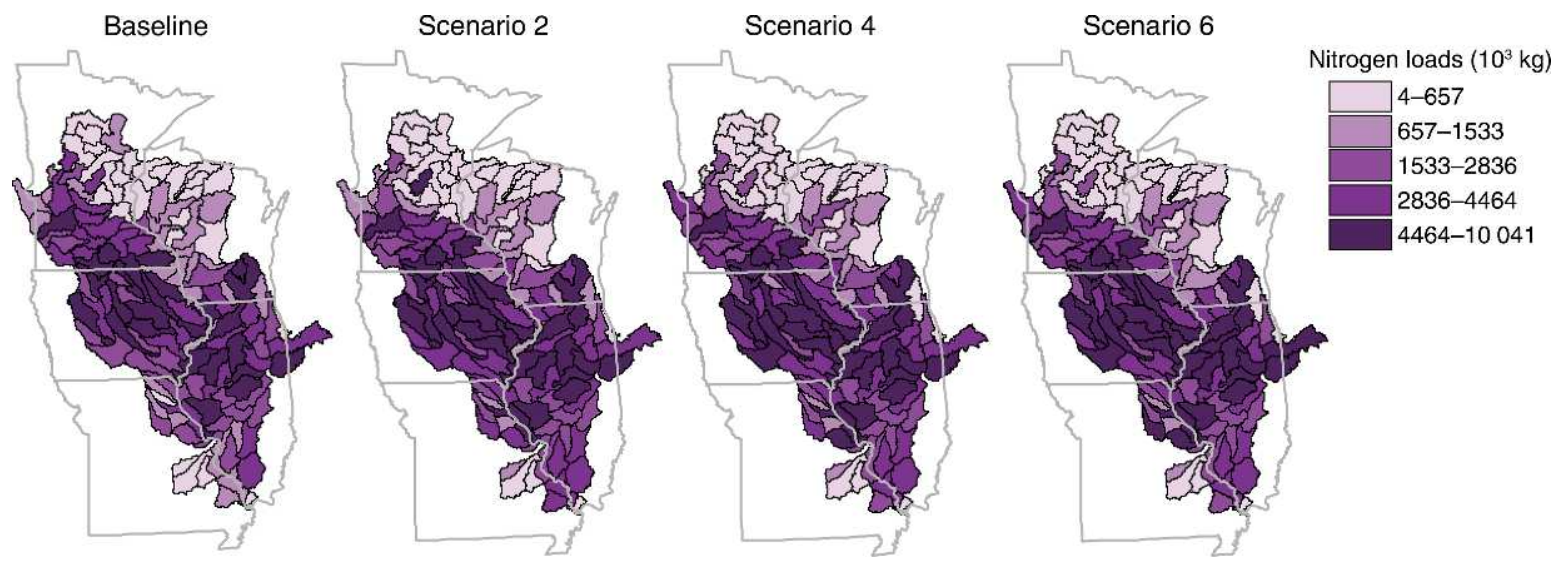

FIG. 6. Nitrogen loads by watershed under the baseline and Scenarios 2, 4, and 6. Values are annual averages. 


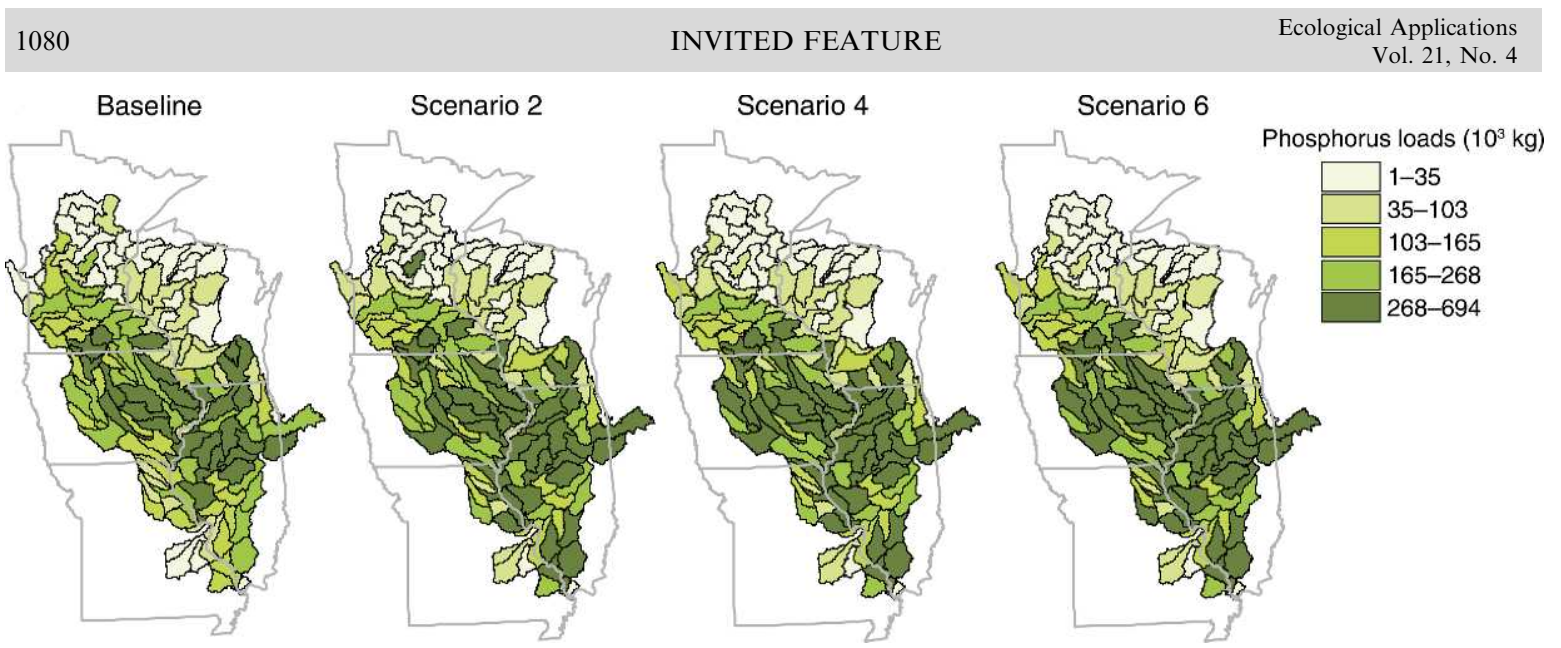

Fig. 7. Phosphorus loads by watershed under the baseline and Scenarios 2, 4, and 6. Values are annual averages.

Donner and Kucharik (2008) estimate that meeting the EISA ethanol mandates by 2022 will result in a $10-$ $34 \%$ increase in nitrogen reaching the Gulf from the Mississippi-Atchafalaya River Basin. Their most aggressive scenario results in an increase in corn acreage of over $60 \%$ which corresponds to the $34 \% \mathrm{~N}$ increase. Our most aggressive Scenario, 6, results in about a $57 \%$ increase in corn acreage with a corresponding $18.5 \%$ increase in $\mathrm{N}$ and $12 \%$ increase in $\mathrm{P}$ at Grafton. Our lower estimates are likely due to our focus on cultivated cropland which is already heavily fertilized.

There are many differences in the models, data employed, geographic regions assessed, and, as we have

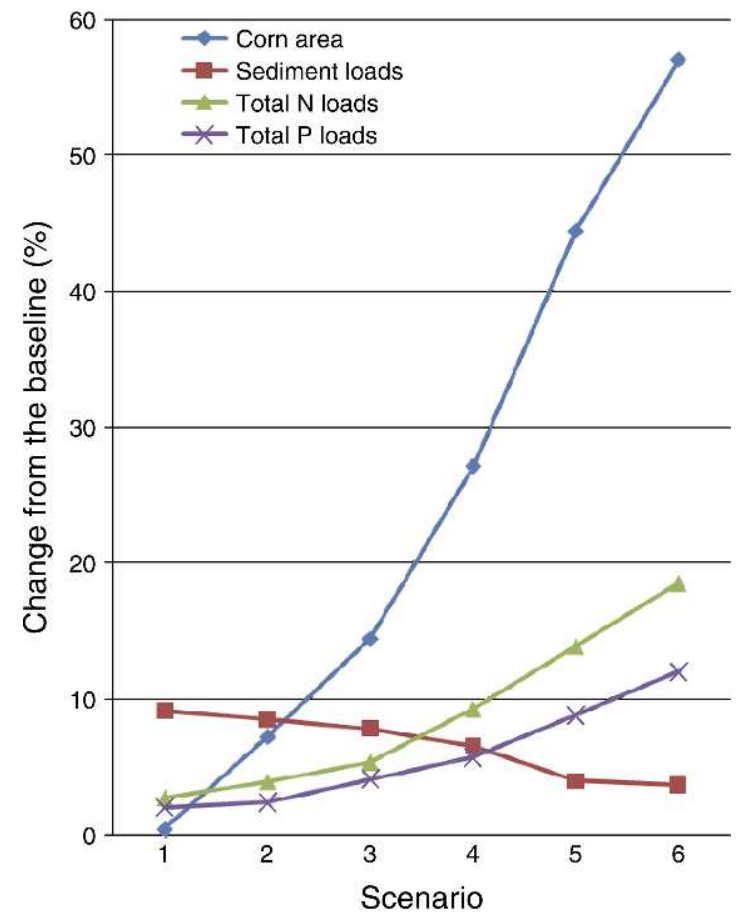

FIG. 8. Percentage change in corn area and in water quality indicators from the baseline. emphasized here, method of allocating land to increased corn production, so one could only speculate on the factors most likely to account for differences in the findings. Given these many differences in models and methods, it seems reasonable to conclude that the findings are broadly consistent and, taken as a whole, paint a fairly uniform picture of the impact of expanded corn-based biofuel on water quality and Gulf hypoxia. As we noted in the introduction, there is widespread agreement in the literature on the large role that agricultural activities play in the hypoxic zone in the Gulf of Mexico (Goolsby and Battaglin 2002, Howarth et al. 2002, Turner and Rabalais 2003, Alexander et al. 2008). In order to offset these activities' impacts on water quality, substantial investments in conservation would be required (Mitsch et al. 2001). However, in the last few years, high crop prices have jeopardized conservation policies (Secchi et al. 2009, 2008) and, as our results show, could worsen pollutant loadings in the Mississippi.

If degradation of water quality is an issue, as suggested by Donner and Kucharik (2008), Simpson et al. (2008), and our own results, it may be appropriate for

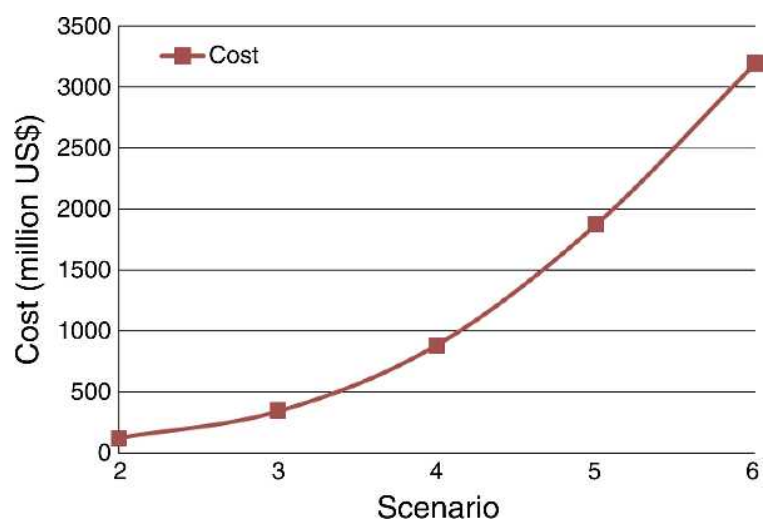

FIG. 9. Cost of maintaining Scenario 1 rotations under five other scenarios' prices. 


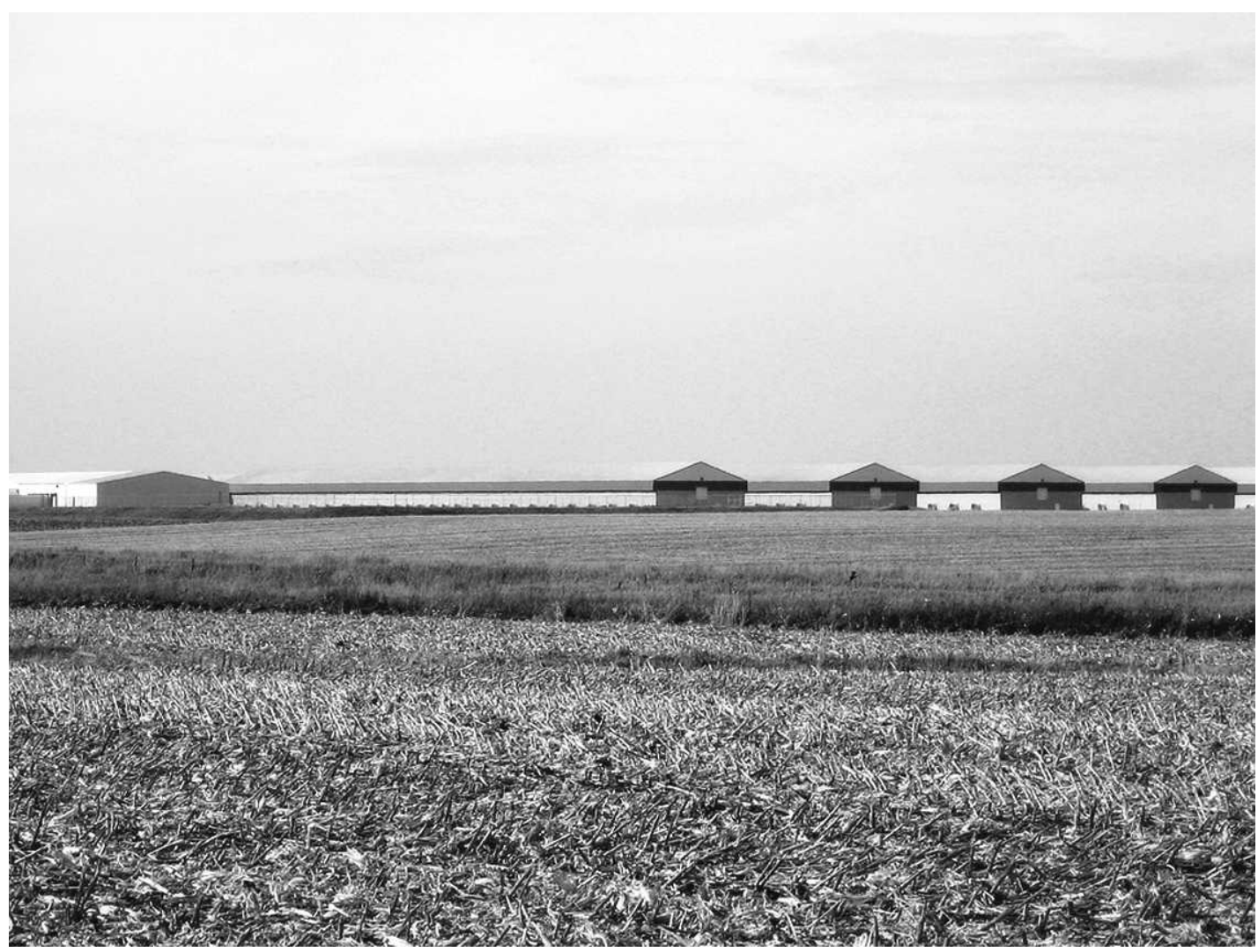

Plate 1. Corn fields before planting in the Boone River watershed (part of the Upper Mississippi River, USA) with an egg operation in the background. Photo credit: P. W. Gassman.

government to consider implementation of policies that counteract these effects by supporting conservation actions that can offset this degradation (such as implementation of buffers, restoration of wetlands, or the elimination of fall fertilizer applications). Alternatively, it may be appropriate to reconfigure the subsidies for ethanol production to favor an alternative feedstock, such as one of the perennial crops: switchgrass or miscanthus.

A number of important caveats should be noted. First, as discussed above, incomplete data on the location and land cover related to the CRP have made accurate representation of its location on the landscape impossible. By representing the current CRP land to be in the same location as the land reported in the 1997, we may be introducing substantive bias, though in which direction we cannot say. Further limitations include the fact that the model systematically underpredicts corn yields (1997-2006) by an average by $12 \%$ and soybeans by over $4 \%$, and our model's lack of consideration of yield drags for rotations. Further, our analysis does not account for manure applications and for gaseous losses of $\mathrm{N}$. This is likely to omit a small but not insignificant portion of the nitrogen cycle. Previous studies have estimated that ammonium deposition accounts for less than $10 \%$ of the nitrogen inputs to cropland from all other sources in the UMRB, including fertilizer and manure (Alexander et al. 2008). As for manure, to the extent that crop price changes do not alter livestock production and manure disposal patterns, our results will not be affected. If, however, livestock practices change dramatically, large-scale changes in manure application and the role of manure in the $\mathrm{N}$ cycle may occur. For example, high animal feed prices and an abundance of distiller's dried grains with solubles (a byproduct of ethanol production palatable to cattle more than to hogs) could cause an increase in cattle inventory in the UMRB. In this case, there could be substantial changes in manure management practices that our framework does not capture. Generally, our analysis points to the necessity of incorporating responses to economic incentives into environmental assessments, and the importance of conducting a wide variety of scenario analyses when uncertainty is high, as it is on future commodity price conditions.

\section{ACKNOWLEDGMENTS}

We thank the participants to the National Conference on Ecological Dimensions of Biofuels, Washington, DC, March 2008, and the Conference "Transition to a Biofuel Economy: Environmental and Rural Development Impacts," St. Louis, Missouri, October 2008, for stimulating discussions and helpful suggestions. This research was made possible in part by USDACSREES grant 2005-51130-02366, USDA-CSREES 2009- 
10002-05149, USDA-NRCS/Prairie Rivers of Iowa RC\&D grant Q6861146200, NSF grant CDI CBET-0835607, and U.S. EPA Collaborative Agreement CR83371701-1. The views expressed here are those of the authors and do not necessarily represent the views or the policies of NSF, USDA, and EPA.

\section{Literature Cited}

Alexander, R. B., R. A. Smith, G. E. Schwarz, E. W. Boyer, J. V. Nolan, and J. W. Brakebill. 2008. Differences in phosphorus and nitrogen delivery to the Gulf of Mexico from the Mississippi River Basin. Environmental Science and Technology 42(3):822-830.

Arnold, J. G., and P. M. Allen. 1996. Estimating hydrologic budgets for three Illinois watersheds. Journal of Hydrology 176(1-4):57-77.

Arnold, J. G., and N. Fohrer. 2005. SWAT2000: current capabilities and research opportunities in applied watershed modeling. Hydrological Processes 19(3):563-572.

Arnold, J. G., R. S. Muttiah, R. Srinivasan, and P. M. Allen 2000. Regional estimation of base flow and groundwater recharge in the Upper Mississippi river basin. Journal of Hydrology 227:21-40.

Arnold, J. G., R. Srinivasan, R. S. Muttiah, and J. R. Williams. 1998. Large area hydrologic modeling and assessment part I: model development. Journal of the American Water Resources Association 34(1):73-89.

Balkcom, K. S., A. M. Blackmer, D. J. Hanswer, T. F. Morris, and A. P. Mallarino. 2003. Testing soils and cornstalks to evaluate nitrogen management on the watershed scale. Journal of Environmental Quality 32:1015-1024.

Bekele, E. G., and J. W. Nicklow. 2005. Multiobjective management of ecosystem services by integrative watershed modeling and evolutionary algorithms. Water Resources Research 41(10):W10406.

Booth, M. S., and C. Campbell. 2007. Spring nitrate flux in the Mississippi River basin: A landscape model with conservation applications. Environmental Science and Technology 41(15):5410-5418.

Borah, D. K., and M. Bera. 2003. Watershed-scale hydrologic and nonpoint-source pollution models: review of mathematical bases. Transactions of the ASAE 46(6):1553-1566.

Borah, D. K., G. Yagow, A. Saleh, P. L. Barnes, W. Rosenthal, E. C. Krug, and L. M. Hauck. 2006. Sediment and nutrient modeling for TMDL development and implementation. Transactions of the ASABE 49(4):967-986.

Breuer, L., K. B. Vache, S. Julich, and H.-G. Frede. 2008. Current concepts in nitrogen dynamics for mesoscale catchments. Hydrological Sciences Journal 53(5):1059-1074.

Diersen, M. A. 2008. Hay price forecasts at the state level Proceedings of the NCCC-134 Conference on Applied Commodity Price Analysis, Forecasting, and Market Risk Management. St. Louis, Missouri, USA. 〈http://www. farmdoc.uiuc.edu/nccc134 $\rangle$

Donner, S., and C. Kucharik. 2008. Corn-based ethanol production compromises goal for reducing nitrogen export by the Mississippi River. Proceedings of the National Academy of Sciences USA 105:4513-4518.

Duffy, M., and D. Smith. 2008. Estimated costs of crop production in Iowa: 2008. File A1-20. Iowa State University Extension, Ames, Iowa, USA. /http://www.extension.iastate. edu/AGDM/crops/pdf/a1-20.pdf $>$

EPA Science Advisory Board. 2008. Hypoxia in the Northern Gulf of Mexico: an update by the EPA Science Advisory Board. EPA-SAB-08-003. 〈http://epa.gov/msbasin/pdf/ sab_report_2007.pdf $>$

Fargione, J., J. Hill, D. Tilman, S. Polasky, and P. Hawthorne. 2008. Land clearing and the biofuel carbon debt. Science 319:1235-1238.

Food and Agricultural Policy Research Institute. 2008. FAPRI 2008 U.S. and world agricultural outlook [08-FSR1]. 〈http:// www.fapri.iastate.edu/outlook2008/>
Food and Agricultural Policy Research Institute. 2009. FAPRI 2009 briefing book. 〈http://www.fapri.iastate.edu/brfbk09/>

Gassman, P. W., M. Reyes, C. H. Green, and J. G. Arnold. 2007. The soil and water assessment tool: historical development, applications, and future directions. Transactions of the ASABE 50(4):1211-1250.

Gassman, P. W., S. Secchi, M. Jha, and L. A. Kurkalova. 2006. Upper Mississippi River Basin modeling system part 1: SWAT input data requirement and Issues. Pages 103-115 in V. P. Singh and Y. J. Xu, editors. Coastal hydrology and processes. Water Resources Publications, Highland Ranch, Colorado, USA.

Goolsby, D. A., and W. A. Battaglin. 2001. Long-term changes in concentrations and flux of nitrogen in the Mississippi River Basin, USA. Hydrological Processes 15(7):1209-1226.

Goolsby, D. A., W. A. Battaglin, G. B. Lawrence, R. S. Artz, B. T. Aulenbach, R. P. Hooper, D. R. Keeney, and G. J. Stensland. 1999. Flux and sources of nutrients in the Mississippi-Atchafalaya River Basin: topic 3 report for the integrated assessment on hypoxia in the Gulf of Mexico. NOAA Coastal Ocean Program Decision Analysis Series No. 17. NOAA Coastal Ocean Program, Silver Spring, Maryland, USA.

Green, W. H., and G. A. Ampt. 1911. Studies on soil physics, 1. The flow of air and water through soils. Journal of Agricultural Sciences 4:11-24.

Hargreaves, G. L., G. H. Hargreaves, and J. P. Riley. 1985. Agricultural benefits for Senegal River Basin. Journal of Irrigation and Drainage Engineering 108(3):225-230.

Howarth, R. W., E. W. Boyer, W. J. Pabich, and J. N. Galloway. 2002. Nitrogen use in the United States from 1961-2000 and potential future trends. Ambio 31(2):88-96.

Jha, M., J. G. Arnold, P. W. Gassman, F. Giorgi, and R. Gu, editors. 2006a. Climate change sensitivity assessment on Upper Mississippi River Basin streamflows using SWAT. Journal of the American Water Resources Association 42(4):997-1015.

Jha, M., P. W. Gassman, and J. G. Arnold. 2007. Water quality modeling for the Raccoon River watershed using SWAT2000. Transactions of the ASABE 50(2):479-493.

Jha, M., P. W. Gassman, S. Secchi, and J. Arnold. 2003. Configuration of SWAT for the Upper Mississippi River Basin: an application to two subwatersheds. Pages 317-322 in Proceedings of the total maximum daily load (TMDL) environmental regulations II. 8-12 November, Albuquerque, New Mexico. American Society of Agricultural Engineers, St. Joseph, Michigan, USA.

Jha, M., P. W. Gassman, S. Secchi, and J. Arnold. $2006 b$. Upper Mississippi River Basin modeling system part 2: baseline simulation results. Pages 117-126 in V. P. Singh and V. J. Xu, editors. Coastal hydrology and processes. Water Resources Publications, Highlands Ranch, Colorado, USA.

Jha, M., P. W. Gassman, S. Secchi, R. Gu, and J. Arnold. 2004a. Effect of watershed subdivision on SWAT flow, sediment, and nutrient predictions. Journal of the American Water Resources Association 40(3):811-825.

Jha, M., Z. Pan, E. S. Takle, and R. Gu. 2004b. Impacts of climate change on streamflow in the Upper Mississippi River Basin: a regional climate model perspective. Journal of Geophysical Research 109:D09105.

Katsvairo, T. W., and W. J. Cox. 2000. Tillage rotation management interactions in corn. Agronomy Journal 92(3): 493-500.

Kline, K. L., V. H. Dale;, J. Fargione, J. Hill, D. Tilman, S. Polasky, P. Hawthorne, and T. D. Searchinger. 2008. Biofuels: effects on land and fire. Science 321:199-201.

Kling, C. L., S. Secchi, M. Jha, H. Feng, P. W. Gassman, and L. A. Kurkalova. 2006. Upper Mississippi River Basin modeling system part 3 : conservation practice scenario results. Pages 127-134 in V. P. Singh and Y. J. Xu, editors. 
Coastal hydrology and processes. Water Resources Publications, Highland Ranch, Colorado, USA.

Koh, L. P., and J. Ghazoul. 2008. Biofuels, biodiversity, and people: understanding the conflicts and finding opportunities. Biological Conservation 141(10):2450-2460.

Lohrenz, S. E., G. L. Fahnenstiel, D. G. Redalje, G. A. Lang, X. G. Chen, and M. J. Dagg. 1997. Variations in primary production of northern Gulf of Mexico continental shelf waters linked to nutrient inputs from the Mississippi River. Marine Ecology Progress Series 155:45-54.

Lohrenz, S. E., D. A. Wiesenburg, R. A. Arnone, and X. G. Chen. 1999. What controls primary production in the Gulf of Mexico? Pages 151-170 in K. Sherman, H. Kumpf, and K. Steidinger, editors. The Gulf of Mexico large marine ecosystem: assessment, sustainability and management. Blackwell Science, Malden, Massachusetts, USA.

McElroy, A. D., S. Y. Chiu, J. W. Nebgen, A. Aleti, and F. W. Bennett. 1976. Loading functions for assessment of water pollution from nonpoint sources. EPA 600/2-76-151. Environmental Protection Agency, Washington, D.C., USA.

Melillo, J. M., J. M. Reilly, D. W. Kicklighter, A. C. Gurgel, T. W. Cronin, S. Paltsev, B. S. Felzer, X. Wang, A. P. Sokolov, and C. A. Schlosser. 2009. Indirect emissions from biofuels: how important? Science 326:1397-1399.

Mitsch, W. J., J. W. Day, Jr., J. W. Gilliam, P. M. Groffman, D. L. Hey, G. W. Randall, and N. Wang. 2001. Reducing nitrogen loading to the Gulf of Mexico from the Mississippi River Basin: strategies to counter a persistent ecological problem. BioScience 51:373-388.

Monteith, J. L. 1965. Evaporation and the environment. Pages 205-224 in The state and movement of water in living organisms, XIXth Symposium. Society of Experimental Biology, Cambridge University Press, Swansea, UK.

Moriasi, D. N., J. G. Arnold, M. W. Van Liew, R. L. Binger, R. D. Harmel, and T. Veith. 2007. Model evaluation guidelines for systematic quantification of accuracy in watershed simulations. Transactions of the ASABE 50(3): 885-900.

Muleta, M. K., and J. W. Nicklow. 2005. Decision support for watershed management using evolutionary algorithms. Journal of Water Resources Planning and ManagementASCE 131(1):35-44.

Nash, J. E., and J. V. Sutcliffe. 1970. River flow forecasting through conceptual models: part I. A discussion of principles. Journal of Hydrology 10(3):282-290.

National Audubon Society. 2000. The changing face of the UMR basin agriculture: selected profiles of farming and farm practices. National Audubon Society, Upper Mississippi River Campaign, St. Paul, Minnesota, USA. 〈http://www. umbsn.org/news/documents/chg_face.pdf $\rangle$

Naylor, R. L., A. J. Liska, M. B. Burke, W. P. Falcon, J. C. Gaskell, S. T. Rozelle, and K. G. Cassman. 2007. The ripple effect: biofuels, food security, and the environment. Environment 49(9):30-43.

Neitsch, S. L., J. G. Arnold, J. R. Kiniry, R. Srinivasan, and J. R. Williams. 2005a. Soil and water assessment tool input/ output file documentation, version 2005. USDA-ARS Grassland, Soil and Water Research Laboratory, Temple, Texas, USA.

Neitsch, S. L., J. G. Arnold, J. R. Kiniry, and J. R. Williams. $2005 \mathrm{~b}$. Soil and water assessment tool theoretical documentation, version 2005. USDA-ARS Grassland, Soil and Water Research Laboratory, Temple, Texas, USA.

Nusser, S. M., and J. J. Goebel. 1997. The national resources inventory: a long-term multisource monitoring programme. Environmental and Ecological Statistics 4:181-204.

Oquist, K. A., J. S. Strock, and D. J. Mulla. 2007. Influence of alternative and conventional farming practices on subsurface drainage and water quality. Journal of Environmental Quality 36(4):1194-1204.
Pikul, J. L., Jr., L. Hammack, and W. E. Riedell. 2005. Corn yield, nitrogen use, and corn rootworm infestation of rotations in the northern corn belt. Agronomy Journal 97:854-863.

Priestly, C. H. B., and R. J. Taylor. 1972. On the assessment of surface heat flux and evaporation using large-scale parameters. Monthly Weather Review 100:81-92.

Rabotyagov, S., T. Campbell, M. Jha, P. W. Gassman, J. Arnold, L. Kurkalova, S. Secchi, H. Feng, and C. L. Kling. 2010. Least cost control of agricultural nutrient contributions to the Gulf of Mexico hypoxic zone. Ecological Applications 20:1542-1555.

Raimbault, B. A., and T. J. Vyn. 1991. Crop rotation and tillage effects on corn growth and soil structural stability. Agronomy Journal 83:979-985.

Randall, G. W., J. A. Vetsch, and J. R. Huffman. 2003. Nitrate losses in subsurface drainage from a corn-soybean rotation as affected by time of nitrogen application and use of nitrapyrin. Journal of Environmental Quality 32:1764-1772.

Renewable Fuels Association. 2010. U.S. fuel ethanol industry biorefineries and capacity. 〈http://www.ethanolrfa.org/ industry/locations/>

Reungsang, P., R. S. Kanwar, M. Jha, P. W. Gassman, K. Ahmad, and A. Saleh. 2007. Calibration and validation of SWAT for the Upper Maquoketa River Watershed. International Agricultural Engineering Journal 169(1-2): $35-48$.

Robertson, G. P., et al. 2008. Sustainable biofuels redux. Science 322:49-50.

Royer, T. V., M. B. David, and L. E. Gentry. 2006. Timing of riverine export of nitrate and phosphorus from agricultural watersheds in Illinois: implications for reducing nutrient loading to the Mississippi River. Environmental Science and Technology 40(13):4126-4131.

Runkel, R. L., C. G. Crawford, and T. A. Cohn. 2004. Load estimator (LOADEST): a FORTRAN program for estimating constituent loads in streams and rivers. U.S. Geological Survey techniques and methods book 4, chapter A5. 〈http:// pubs.usgs.gov/tm/2005/tm4A5/>

Santelman, M. V., et al. 2004. Assessing alternative futures for agriculture in Iowa, U.S.A. Landscape Ecology 19:357-374.

Sawyer, J., E. Nafziger, G. Randall, L. Bundy, G. Rehm, and B. Joern. 2006. Concepts and rationale for regional nitrogen rate guidelines for corn. Iowa State University Extension, Ames, Iowa, USA. 〈http://www.extension.iastate.edu/ Publications/PM2015.pdf $\rangle$

Schomberg, J. D., G. Host, L. B. Johnson, and C. Richards. 2005. Evaluating the influence of landform, surficial geology, and land use on streams using hydrologic simulation modeling. Aquatic Sciences 67:528-540.

Seaber, P. R., F. P. Kapinos, and G. L. Knapp. 1987. Hydrologic Unit Maps. U.S. Geological Survey WaterSupply Paper 2294. U.S. Geological Survey, Reston, Virginia, USA.

Searchinger, T., R. Heimlich, R. A. Houghton, F. Dong, A. Elobeid, J. Fabiosa, S. Tokgoz, D. Hayes, and T. Yu. 2008. Use of U.S. croplands for biofuels increases greenhouse gases through emissions from land-use change. Science 319:12381240.

Secchi, S., P. W. Gassman, M. Jha, L. Kurkalova, H. H. Feng, T. Campbell, and C. L. Kling. 2007. The cost of cleaner water: assessing agricultural pollution reduction at the watershed scale. Journal of Soil and Water Conservation 62(1):10-21.

Secchi, S., P. W. Gassman, J. R. Williams, and B. A. Babcock. 2009. Impact of high crop prices on environmental quality: a case of Iowa and the Conservation Reserve Program. Environmental Management 44:732-744.

Secchi, S., J. Tyndall, L. A. Schulte, and H. Asbjornsen. 2008. High crop prices and conservation: raising the stakes. Journal of Soil and Water Conservation 63(3):68A-73A. 
Shepherd, B., D. Harper, and A. Millington. 1999. Modelling catchment-scale nutrient transport to watercourses in the U.K. Hydrobiologia 395-396:227-237.

Simpson, T., A. Sharpley, R. Howarth, H. Paerl, and K. Mankin. 2008. The new gold rush: fueling ethanol production while protecting water quality. Journal of Environmental Quality 37:318-324.

Singh, V. P. 1995. Computer models of watershed hydrology. Water Resource Publications, Highlands Ranch, Colorado, USA.

Srivastava, P., K. W. Migliaccio, and J. Šimůnek. 2007. Landscape models for simulating water quality at point, field, and watershed scales. Transactions of the ASABE 50:1683-1693.

Stern, A. J., P. C. Doraiswamy, and B. Akhmedov. 2008. Crop rotation changes in Iowa due to ethanol production. Geoscience and Remote Sensing Symposium, 2008. IGARSS 2008. IEEE International 5:V-200-V-203.

Sylvan, J. B., Q. Dortch, D. M. Nelson, A. F. Maier Brown, W. Morrison, and J. W. Ammerman. 2006. Phosphorus limits phytoplankton growth on the Louisiana shelf during the period of hypoxia formation. Environmental Science and Technology 40:7548-7553.

Takle, E. S., M. Jha, and C. J. Anderson. 2006. Hydrological cycle in the Upper Mississippi River basin: 20th century simulations by multiple GCMs. Geophysical Research Letters 32:L18407.

Tokgoz, S., A. Elobeid, J. Fabiosa, D. J. Hayes, B. A. Babcock, T.-H. Yu, F. Dong, C. E. Hart, and J. C. Beghin. 2007. Emerging biofuels: outlook of effects on U.S. grain, oilseed, and livestock markets. Center for Agricultural and Rural Development Staff Report 07-SR 101. 〈http://www.card. iastate.edu/publications/DBS/PDFFiles/07sr101.pdf $\rangle$

Turner, R. E., and N. N. Rabalais. 2003. Linking landscape and water quality in the Mississippi River Basin for 200 years. BioScience 53:563-572.

Turner, R. E., N. N. Rabalais, and D. Justiç. 2008. Gulf of Mexico hypoxia: alternate states and a legacy. Environmental Science and Technology 42(7):2323-2327.

U.S. Department of Agriculture. 2008. USDA announces CRP permitted use for livestock feed needs: eligible CRP acres allowed to hay and graze; $\$ 1.2$ billion forage made available. Press Release No. 0137.08. 〈http://www.fsa.usda.gov/FSA/ newsReleases?area $=$ newsroom\&subject=landing\&topic $=$ ner\& newstype $=$ newsrel\&type $=$ detail\&item $=n r \_20080527$ _rel_ 0137.html

U.S. Department of Agriculture. 2009. USDA agricultural projections to 2018. Office of the Chief Economist, World Agricultural Outlook Board, Prepared by the Interagency Agricultural Projections Committee Long-term Projections Report OCE-2009-1. 〈http://www.ers.usda.gov/Publications/ OCE091/OCE091.pdf $\rangle$
U.S. Department of Agriculture-Economic Research Service. $2007 a$. U.S. fertilizer use and price. 〈http://www.ers.usda. gov/Data/FertilizerUse/>

U.S. Department of Agriculture-Economic Research Service. 2007b. Farm business and household survey data: customized data summaries from ARMS. 〈http://www.ers.usda.gov/ Data/ARMS/app/Crop.aspx $>$

U.S. Department of Agriculture-National Agricultural Statistical Service. 2009. Agricultural statistics data base. 〈http:// www.nass.usda.gov/Data_and_Statistics/Quick_Stats/>

U.S. Department of Agriculture-Natural Resources Conservation Service. 2004. Estimation of direct runoff from storm rainfall. Pages 10.1-10.22 in NRCS national engineering handbook: part 630, hydrology. USDA Natural Resources Conservation Service, Washington, D.C., USA. 〈http:// directives.sc.egov.usda.gov/viewerFS.aspx?hid=21422>

U.S. EPA. 2006. Better assessment science integrating point and nonpoint sources (BASINS). U.S. Environmental Protection Agency, Washington, D.C., USA. 〈http://www.epa.gov/ waterscience/basins/>

U.S. Geological Survey. 2009. Federal guidelines, requirements and procedures for the National Watershed Boundary Dataset. U.S. Geological Survey, U.S. Department of the Interior, Reston, Virginia and Natural Resources Conservation Service, U.S. Department of Agriculture, Washington, D.C., USA. 〈ftp://ftp-fc.sc.egov.usda.gov/NCGC/products/ watershed/hu-standards.pdf

Vyn, T. J., T. D. West, and G. C. Steinhardt. 2000. Corn and soybean response to tillage and rotation systems on a dark prairie soil: 25 year review. No. 196. Pages $1-10$ in Proceedings, 15th Conference of International Soil Tillage Research Organization, July 2-6, 2000, Fort Worth, Texas. International Soil Tillage Organization, Madison, Wisconsin, USA.

Wilhelm, W. W., and C. S. Wortmann. 2004. Tillage and rotation interactions for corn and soybean grain yield as affected by precipitation and air temperature. Agronomy Journal 96:425-432.

Williams, J. R., and R. W. Hann. 1978. Optimal operation of large agricultural watersheds with water quality constraints. Texas Water Resources Institute, Technical Report No. 96. Texas A\&M University, College Station, Texas, USA.

Wu, J., R. Adams, C. Kling, and K. Tanaka. 2004. Assessing the costs and environmental consequences of agricultural land use changes: a site-specific, policy-scale modeling approach. American Journal of Agricultural Economics $86: 26-42$

$\mathrm{Wu}$, J., and K. Tanaka. 2005. Reducing nitrogen runoff from the Upper Mississippi River basin to control hypoxia in the Gulf of Mexico: easements or taxes. Marine Resource Economics 20:121-144. 